\title{
Representative versus Responsible Government and May's Law: The Case of the Czech Christian Democratic Party*
}

\author{
LUKÁŠ LINEK and PAT LYONS** \\ Institute of Sociology AS CR, Prague
}

\begin{abstract}
The representative vs responsible government thesis of Peter Mair argues that one of the main causes of the weakening of democracy is the increasing tension between the representative and governance functions performed by parties. The consequences of this widening gap in roles are increasingly evident, however, little is known about the intra-party foundations of this trend. This study using May's law and a theoretically informed case study of the Czech Christian Democratic Party (KDU-ČSL) demonstrates that (1) the opinion structure with a governance rather than representation oriented party is largely homogeneous revealing the origins of the representation deficit; and (2) the observed opinion differences among members of a party frequently in government have their origins in society rather than within the party showing that internal party life is failing in its representation function. These two results demonstrate that fundamental changes in party system have intra-party foundations.
\end{abstract}

Keywords: representative versus responsible government, party members, May's Law, policy positions, Czech Christian Democratic Party

Sociologický časopis/Czech Sociological Review, 2011, Vol. 47, No. 6: 1149-1190

In this article, we will examine through use of a theoretically informed case study what happens to the internal workings of a political party if its governing function comes to dominate its representative role. Mair [2005, 2008, 2009, 2011] in a series of influential papers convincingly argued that the growing incompatibility between a party's representative and governance functions is 'one of the principal sources of the democratic malaise that confronts many Western democracies today' [Mair 2009: 1]. Mair's 'representative versus responsible government' thesis may be unpacked into four main claims.

First, parties participating in government must act responsibly and fulfil the conditions of long-standing agreements resulting from membership of the EU, UN, NATO, WTO, etc. Second, governing parties must be responsive to both

* This article was prepared as part of the work on the research project supported by Czech Science Foundation 'Continuity and Change in Electoral Behaviour in the Czech Republic between the Years 1990-2009' (grant no. P408/10/0584).

** Direct all correspondence to: Lukáš Linek and Pat Lyons, Institute of Sociology AS CR, Jilská 1, 11000 Prague 1, e-mail: lukas.linek@soc.cas.cz, pat.lyons@soc.cas.cz.

(C) Sociologický ústav AV ČR, v.v.i., Praha 2011 
domestic public opinion and external obligations and pressures. Third, public opinion has become more fragmented and it is increasingly difficult for parties to understand and hence be responsive to citizens' concerns and wishes. Fourth, the strong social links anchoring political parties in society have weakened to such an extent that non-partisan groups now often have a greater claim over citizens' policy preferences.

Mair's representative versus responsible government thesis has thus far focused on the conceptual, normative, and more particularly the 'external' implications of his compelling argument [cf. Mair 2011]. What is lacking is an empirical study of how this trend towards responsible rather than representative government is reflected in 'internal' party politics. In this study, it will be argued that the external characteristics identified by Mair [2009] will have complementary intra-party features. Specifically, the fact that a party is more oriented towards governance than representation will be evident in the attitudes of party members. Political parties that are continuously dominated by the burdens of government will develop an attitudinal profile that reflects the priorities of the party leadership and government. In short, there will be homogeneity in party members' policy positions.

Members of the party that emphasise the representative function of the party through espousing 'extreme' issue positions will disappear through the self-reinforcing mechanisms of attrition and selective (non-ideological) recruitment. One of the most influential models of the structure of opinion within political parties is May's law which asserts that the representative feature of parties is evident in a curvilinear pattern of opinions where middle ranking party members will express more 'extreme' policy positions than either party leaders, rank-and-file members or party voters [May 1973]. A subsequent revision of this curvilinear model by Kitschelt [1989] argued that it was the ideological orientation rather than position in a party that was the foundation of political parties' representative function in a polity.

The contribution of this article to the study of political parties is its combining of insights from Mair's [2009] representative versus responsible government thesis and May's law literature. Using unique party members survey data for a party that has been frequently in office over a prolonged period, this study will explore the idea that governance oriented parties will not exhibit the curvilinear disparities predicted by May [1973] or Kitschelt [1989] because the representative function of the party has been subsumed to the responsibilities of being in government. In short, this article will do two things. First, it will comprehensively

\footnotetext{
${ }^{1}$ Recent events in Greece and Italy in late 2011 demonstrate what happens when political parties fail in both their representative and responsibility functions. Under external constraints, representative democracy is essentially suspended because parties are seen to be dysfunctional and incapable of effective governance. Moreover, citizens accepted the emergence of 'technocratic governments' in Greece and Italy as both inevitable and desirable, thus showing the fundamental weakness of parties within contemporary European democracies.
} 
test the null hypothesis (across ten policy domains) that there are no significant differences in attitudes among members of a political party that has embraced a governance role. Second, this study will show through a series of regression models that in a party that suppresses its representation function, the main determinants of intra-party attitude differences will not lie in party structures, but will have their origins in society and more specifically in party members' position in the social rather than party hierarchy. ${ }^{2}$

Before proceeding it is crucially important at this point to justify the case study used in this article. In order to examine the intra-party implications of Mair's representative versus responsible government thesis it is necessary to identify a very specific type of party with three key characteristics. First, we need a party that has a long, distinct ideological tradition devoted to representing a specific set of policies. Second, this party must have extensive experience in government and preferably as a junior coalition partner where there has been a definite adoption of a responsible government versus citizen representation role. Third, empirical data on the attitudes of members of this party are required in order to test for curvilinear disparities in intra-party opinions. A survey of members of the Czech Christian Democratic Union-Czechoslovak People's Party (KDU-ČSL, hereafter the Czech Christian Democratic Party) fulfils all three criteria. In order to justify this claim some explanatory comments are in order.

The Czech Christian Democratic Party (KDU-ČSL) represents a specific tradition within Czech political culture that can trace its origins back more than a century. The strength of these representative roots is indicated by the fact that a Christian Democratic Party has always been present in national Czech politics under a variety of names (see the Christian Democratic Party section of this article for details). Christian Democrats were legislators during the later phases of the Habsburg Empire (1860-1918), the First Republic (1918-1938), the communist regime (1948-1989), and under the current regime (since 1990). Over the last two decades, KDU-ČSL has been in government more often than almost any other Czech political party because it has participated in coalition governments on both the left and right. Of course, this small party's frequent (and almost continuous) participation in government has involved accepting a succession of 'compromise' policy platforms. The costs of such a strategy fit with Mair's [2009] argument.

First, there has been a secular decline in KDU-ČSL party membership during its time in government. Second, the party's reputation has steadily declined in the eyes of the electorate. ${ }^{3}$ Third, this loss of reputation was reflected in the party eventually failing to enter parliament as its voting base shrank below the electoral

\footnotetext{
2 The concept of representation used in this article follows the one adopted by Mair [2009].

${ }^{3}$ By 2010 the perception that the party was primarily office-seeking in orientation was evident in the large number of negative responses to an open-ended question, in the Czech National Election Study, which asked interviewees what words came to mind when the name 'KDU-ČSL' was mentioned. This party image theme is the subject of on-going research and will not be presented here.
} 
threshold in the Chamber Elections of 2010. Fourth, although the KDU-ČSL party leadership split in 2009 resulting in the creation of a new rival party (TOP 09), very few members of KDU-ČSL participated in this process revealing a party membership with few ideological divisions. More will be said about our case study in later sections.

We begin this article with a brief overview of May's special law of curvilinear disparity, and this is followed by Kitschelt's [1989] critique and extension of the curvilinear disparity thesis. In the third section, there is a discussion of the organisational history of KDU-ČSL and its position within the Czech party system. Thereafter, we outline why KDU-ČSL is a pertinent case study of intra-party attitudes and present expectations for the analysis of KDU-ČSL opinion structure derived especially from May and Kitschelt. Section four contains a description of the research methodology employed in our data analysis. In the penultimate section, we present our results regarding differences of opinion between different strata within the KDU-ČSL party and its voters in the 2006 general election. We conclude by discussing some of the key findings from our case study.

\section{May's special law of curvilinear disparity}

It is important to stress from the outset that John May [1973] discussed five different models of disparity when considering the differing attitudes of party leaders, sub-leaders, and voters. In fact, he devoted the first section of his seminal article to this topic because he wanted to stress the fact that intra-party conflicts occur for a variety of reasons, and there is unlikely to be a general model that could explain all such conflicts. ${ }^{4}$ Using an inductive approach informed by classic sociological perspectives on 'major and semi-major' parties within established democracies, May [1973] proposed his special law of curvilinear disparity to explain what he saw as the typical opinion structures within modern political parties.

May's special law has been neatly summarised as follows: 'Voters usually take the most moderate line on issues, sub-elites prove the most ideologically extreme, whereas top elites are located somewhere in between these two levels. The reason for this curvilinear pattern, May argues, has to do with different incentives for the actors to become involved in, and to continue to participate in, party politics.' [Narud and Skare 1999: 45] ${ }^{5}$ In this respect, May made three key assumptions about political parties and their opinion structures.

\footnotetext{
${ }^{4}$ For example, May's [1973: 138] 'Leaders as Extremists' model may be explained using a directional issue voting logic, while his 'Leaders as Centrists' model would seem to fit a proximity issue voting logic [see Narud and Skare 1999: 61-62].

${ }_{5}$ Norris [1995: 30] interpreted May's law as meaning top party leaders would be 'equidistant' between moderate voters and ideologically extreme sub-leaders. In fact, May [1973: 139] explicitly stated 'top leaders occupy an intermediate position (but not an exact mid-way position) between the median opinions of sub-leaders and their non-leaders (voters)'. Thus May's law is not as special as Norris [1995] suggests.
} 
First, party organisations are inherently hierarchical and may be divided into at least two strata-leaders and sub-leaders. In addition, there are party voters who are simply predisposed to support the party during some elections. While May [1973: 135-136] did give a detailed description of a generic US party structure, he was vague about how party hierarchy could be defined more generally. He suggested using very broad strata based on status, i.e. high, intermediate, and low. Later researchers have tended to use varying stratification schemes ranging from two to six categories. Quite obviously being able to stratify a party correctly is fundamentally important. Unfortunately, there is no definitive method for undertaking this task.

Second, party members within different strata perform different tasks within the party. Because of this functional differentiation members from different levels within any party have varying motivations to undertake their specific tasks. Typically, these variations are seen to stem from 'different incentives'. A number of authors have interpreted this assumption in loosely rational choice or Downsian terms. From this perspective, party leaders have office-seeking motivations while party members are policy oriented [Norris 1995: 30-32; Narud and Skare 1999: 46-47]. In this respect, it should be stressed that May [1973] made no reference to Downs [1957] or any other rational choice scholar. His insights are based on the (sociological) works of Ostrogorski [1910], Michels [2009], Key [1958], Duverger [1964], Epstein [1965], and other specialised works. In contrast, May [1973: 143-151] did not adopt a policy versus office seeking perspective toward intra-party politics but stressed instead the importance of three interrelated sociological factors: (a) organisational forms of intra-party control; (b) selective recruitment to different party echelons; and (c) political socialisation patterns within parties. In short, May explained the different incentives among party members in terms of group rather than individual level motivations.

Third, with regard to the opinion structure within political parties May [1973] was primarily interested in explaining differences in issue position, and not the salience of issues. Moreover, he deliberately stated that his model did not refer to key ideological cleavages. Therefore, if the left-right cleavage defines party competition in a state it should not be used to explore May's law. However, May himself confused matters by discussing opinion structures in terms of single dimensions such as left-right. Such confusion reveals that May had no clear expectation as to which 'substantive opinions' would form the basis of his special curvilinear disparity law. The implication here is that different issues will underpin his 'special' form of intra-party conflict in different countries at different points in time. Such flexibility comes at a cost because it becomes difficult to gauge the validity of May's law [Narud and Skare 1999: 61]. For example, if we observe curvilinear disparity across one, a few, or many issue domains; how should we interpret these results?

In summary, May [1973] proposed an elegant intuitive theory of why opinion structures within political parties should be patterned on the basis of its organisational (hierarchical) structure. Empirical tests of May's law have often found little 
evidence for his curvilinear disparity thesis [Herrera and Taylor 1994; Whiteley, Seyd and Richardson 1994; Norris 1995; Narud and Skare 1999; Seyd and Whiteley 2002; Whiteley and Seyd 2002]. However, other research based in part on extensions of May's law have found some support for curvilinear disparity between voters, members, and leaders [Kitschelt 1989; Seyd and Whitely 1992; Kennedy, Lyons and Fitzgerald 2006]. His detailed sociological model explaining curvilinear disparity has never been tested because the data requirements for such a test are prohibitive. It is ironic therefore that May's original article has been strongly criticised for oversimplifying reality. It is to these criticisms that we now turn.

\section{Critiques of May's special law of curvilinear disparity}

Although May's law has considerable intuitive appeal, empirical testing of his model has led to mixed results [Jackson, Brown and Bositis 1982; Rapoport, Abramowitz and McGlennon 1986; Kitschelt 1989; Seyd and Whitely 1992; Iversen 1994; Herrera and Taylor 1994; Norris 1995; Kennedy, Lyons and Fitzgerald 2006]. ${ }^{6}$ Scholars have been unsure whether these difficulties stem from methodological problems arising from data limitations, or arise instead from limitations in the theory underpinning May's law. These methodological issues may be summarised as follows: (a) testing on a restricted range of countries, most of which have two-party systems with plurality electoral laws; (b) running analyses on a restricted range of party strata; (c) imputing rather than measuring voters issue positions; and (d) testing opinions on a restricted range of issue domains.

In contrast, theoretical concerns have centred firstly on May's [1973] imputed 'reductionist psychology' where he is accused of failing to appreciate the mixed motivations faced by all party members. This is a little surprising since May did not propose an individual level model of party member motivation. Secondly, the special law of curvilinear disparity has been criticised for making little reference to the likely impact of different levels of issue-based conflict. Presumably this problem arises because May's law specifically eschews discussion of issue salience. Thirdly, the special pattern of curvilinear disparity described by May is not observed in empirical studies. This is because May's law is in reality only a partial explanation.

In fact, the most systematic re-appraisal and extension of the curvilinear disparity law has stemmed from this last theoretical critique of May's law. Kitschelt [1989] starts off by arguing that party members should be defined primarily in terms of their attitudinal orientation, i.e. ideologues or pragmatists, rather than formal position in a party. This crucial shift in emphasis hinges on what is the causal relationship underpinning party membership—do members select their

\footnotetext{
${ }^{6}$ Within the literature on May's law there are frequent references to research that predate May's [1973]. For the articles that are evaluated as testing essentially the same idea, note McClosky, Hoffman and O'Hara [1960]; Constantini [1963]; and Soule and Clarke [1971].
} 
party, or does the party select its members? For Kitschelt a member's initial ideology predisposes them psychologically to join, or aspire to join a specific stratum within a party. Thus attitudes motivate behaviour. In contrast, May held that different party strata selectively recruit and socialise their members. Therefore, in this scenario parties recruit 'suitable' members and hence party position determines opinions. This is because institutionalised sociological selection rather than psychological mechanisms underpin party membership in the first place. Quite obviously, these differences stem from May's collectivist and Kitschelt's individualist a priori assumptions.

These differences have important consequences because May's Law endogenises intra-party conflict, and associated attitudinal differences. In contrast, Kitschelt (partly) exogenised intra-party conflict by making reference to factors such as social cleavages, the structure of party competition, and electoral history. Ideologues and pragmatists in essence emerge fully formed from society into parties. Therefore, according to Kitschelt high levels of ideological division within society combined with strong party competition and a history of electoral failure promote curvilinear disparities. Moreover, these exogenous factors are enhanced if a party lacks hierarchical rigidity where ideologues are free to do as they please.

\section{The Czech Christian Democratic Party (KDU-ČSL)}

Our case study focuses on the Czech Christian Democratic Party (KDU-ČSL) which has its origin in a number of Catholic parties established in both parts of the Czech Republic, i.e. Bohemia and Moravia, in the late 19th century. ${ }^{7}$ In both areas, these parties adhered to either a Christian socialist or Catholic national ethos. With independence from the Austro-Hungarian Empire in 1918, all the main Czech Catholic parties merged into the Czechoslovak People's Party (ČSL). The key reason for this consolidation stemmed from pressure from an anti-Catholic movement who mounted a campaign arguing that the Catholic Church had collaborated with the former Habsburg regime. One effect of this merger was programmatic divisions within the party arising from the different interests of Christian trade unionists and small agricultural freeholders.

During the interwar period, ČSL gained between $7 \%$ and $11 \%$ of the popular vote in national elections, and after 1921 it participated in all Czechoslovak governments. The main goals of ČSL during the First Republic (1918-1938) was to maintain the link between church and state, to lobby for increased salaries for

\footnotetext{
${ }^{7}$ More detailed history of the origins and development of Catholic political parties in the Czech Republic and the Czechoslovak People's Party are given by Trapl [2000, 2004a, 2004b] and Lukeš [2004]. These reviews are used for the description of the party given here. Note also Balík and Hanuš [2007] and Fiala et al. [2008] on the Catholic Church under communism For an overview of the development of the Czech party system in the nineties, see Fiala, Mareš and Pšeja [1999] and Kostelecký [2002].
} 
church officials, to secure state financing of theological institutes and to gain exemptions for the Catholic Church from land reforms.

After liberation by Soviet (and American) troops at the end of the Second World War, ČSL was the only non-socialist political party that was allowed under the new Czechoslovak regime. After the communist coup of 1948, non-socialist (or 'satellite') parties were allowed to continue organisationally even though they were compelled to accept the dictates of the Communist Party (KSČ) leadership. Strict restrictions were put on ČSL party membership, as all party members had to undergo a re-validation of their membership with many anti-communist members being prohibited from re-joining. This resulted in a decline in membership from more than four hundred and sixty thousand in 1948, to just thirty thousand in 1949. Thereafter, during the 1950s ČSL membership dropped further to twenty thousand-a limit that the Communist Party unofficially set for total ČSL membership. In response to such adverse circumstances, party activity switched to organising voluntary work, pilgrimages, trips to sacred monuments, and holding cultural events. The party held one ministerial seat in the Czechoslovak cabinet and had more than ten members of parliament and a deputy speaker in the National Parliament.

There was a brief upsurge in party membership with the Prague Spring of 1968, when party numbers swelled to more than seventy thousand. However, during the following period of 'normalisation', when a hard-line communist orthodoxy was imposed, ČSL membership declined rapidly once again and the party was again not allowed to recruit new party members above a certain limit. By 1971 it had dropped to forty thousand, as anti-socialist/Soviet elements were expelled from the party. Moreover, ČSL lost its cabinet positions at both the national and federal level and had only a minister without portfolio in the Czech cabinet. By the 1980s, the Czech Secret Police (StB) described ČSL as mounting little threat to state security, as it was seen as little more than a pensioner's organisation [Lukeš 2004: 1300].

Following the Velvet Revolution of 1989, ČSL merged with other small Catholic parties and renamed itself the Christian Democratic Union-Czechoslovak People's Party (KDU-ČSL). One reason for this strategy was to distance itself from accusations of cooperation with the communist regime. The new name also reflected a new vision for the party and potential affiliation with the German Christian Democrats (CDU/CSU). Although KDU-ČSL party membership increased dramatically to almost one hundred thousand by the end of 1990, the party was unable to build an extensive electoral base. Between 1990 and 2006, KDU-ČSL received between six and nine percent of the popular vote. Nonetheless, this party has been influential through participation in successive governing coalitions, i.e. between 1992 and 1998, and thereafter between 2002 and 2009.8

${ }^{8}$ In comparative terms, there are relatively few Christian Democratic parties in post-communist countries. The presence of this party family in a country appears to be strongly influenced by the historical development of party systems where this type of party existed 
Following the Chamber elections of 2006 there was considerable wrangling within the party because of scandals and policy differences. All of this culminated in a party split in June 2009 when a former party leader (Miroslav Kalousek) established a new party called TOP 09 (Tradice, odpovědnost, prosperita 09 or Tradition, Responsibility, Prosperity 09). An important point to note in the context of this research is that this process of party fission was largely a party elite affair: very few rank and file members of KDU-ČSL opted to join TOP 09. This means that the origins of this party fission are not likely to be evident in the intra-party policy attitudes examined in this study. In policy terms, TOP 09 is more right wing (free market and fiscally conservative) on economic issues than KDU-ČSL; and this may help explain why Christian Democratic party members stuck with their party in 2009.

A year later in the general election of 2010, KDU-ČSL's level of popular support declined below the electoral threshold of $5 \%$. As a result, for the first time since 1990, there is no Christian Democrat representation in the current lower chamber (2010- ). In contrast, TOP 09 under the popular leadership of Karel Schwarzenberg was very successful in its first general election becoming the third largest party in the Chamber of Deputies with 41 seats [for details, see Linek 2011].

A key feature of KDU-ČSL examined in this study is the formal organisational structure of the party, as May [1973] suggests we should observe systematic attitudinal differences among members at different levels. Organisationally, KDU-ČSL has four operational strata: local, district, regional, and national. This structure parallels the Czech system of governance and elections, with the exception of the district level. There are almost no restrictions on joining the party; however, before 1995 the applying member had to have recommendations from two party members. The constitution of party bodies is undertaken using intra-party elections. Party members sitting in national and regional assemblies, and who are government ministers are allocated ex officio seats on the national and regional executive boards of the party. In the early 1990s, the national executive committee controlled which candidates were included on the party's regional lists and decided upon the order. Thereafter, this power was devolved to regional party organisations. Since 1996 the party has adopted a decentralised system of candidate selection where regional organisations have the option to hold primary elections, if they wish. More often, candidate selection is undertaken by local delegates at the regional level [see Enyedi and Linek 2008].

Programmatically, KDU-ČSL is on the centre right, where its policy platform can be summarised in one of its electoral campaign slogans where it advocates for a 'social market economy'. More specifically, in the post-communist setting this means that the party favours limiting public spending and reducing the size of the public sector. However, KDU-ČSL supports progressive taxation.

prior to communism. In general, Christian Democratic parties have not fared well during the post-communist era and most appear to be experiencing declining levels of support [Grzymala-Busse 2011]. 
With regard to other key issues the party supports the process of European integration, and adopts a conservative stance on moral issues such as abortion, same sex partnerships, gender roles, and family policy. It also supports stricter measures against criminals, opposes gambling, and supports restitution of property to the Catholic Church seized by the communist regime. In the post-communist era, however, few of these issues have been salient in elections. For example, issues such as abortion or homosexuality are not key mobilising factors. The party doesn't electorally compete that much on the socioeconomic left-right axis as it stresses moral issues.

\section{Case selection and theoretical expectations}

In this article, we have two central objectives. First, we will investigate if position within a party is associated with systematic opinion differences. More specifically, we will test if middle-ranking party members exhibit more extreme attitudes than either voters or party leaders. Second, we will explore Kitschelt's [1989] extension of May's law and see if differentiating party members into pragmatists and ideologues is associated with a progression in the extremeness of opinions from voters to pragmatists and finally ideologues. ${ }^{9}$ We do not provide a comprehensive test on all parties in the Czech party system, but we attempt instead to explore if the special law of curvilinear disparity has application for a small centrist party in the Czech Republic.

\section{Application of May's law to KDU-ČSL}

In the opening paragraph of his famous article, May [1973: 135] states that he is presenting a 'general theory of political party structure . . the theory is not general, however, in coverage of party structure. Its primary concern is hierarchical contrasts in substantive opinion. It deals with contrasting opinions not about basic values or extant conditions but about immediate policy alternatives ....' At the risk of repeating points highlighted earlier in section one, two key implications follow from this statement. First, it is legitimate to test May's law in multiparty systems because it is a general law covering all party systems with open electoral competition [May 1973: 135, 141; note Narud and Skare 1999]. Therefore, our KDU-ČSL case study is appropriate to test May's law. Second, the special law of curvilinear disparity applies only to opinions and policy alternatives. May's law does not refer to ideological structure of parties. In the case of KDU-ČSL this

\footnotetext{
9 Additional research was undertaken to see if the level of party activism is also associated with attitudinal differences. Our results revealed that level of activism and position in the party are strongly correlated. For the sake of brevity we do not report here our party activism and issue scale position results.
} 
means May's law should not be tested with left-right and abortion scales as they both refer to 'basic values', as mentioned in section 1, rather than opinions about 'immediate policy alternatives'.

Beyond the general predictions made by May of observing a curvilinear disparity in opinions within parties; he made only a few specific comments regarding 'centre parties' such as KDU-ČSL. His most specific prediction is that: 'In a generally Left-of-Centre party they [sub-leaders] are the most Leftist cohort; in a generally Right-of-Centre party they are the most Rightist cohort.' [May 1973: 139]

It is fundamentally important to understand here that the terms left and right refer to the overall ideological position of specific parties within a system of inter-party competition. When discussing intra-party politics the terms 'left', 'right', and 'centre' refer to relative opinion (not ideological) positions in a unidimensional 'policy alternative' space defined by two polar ends of the scale. Here 'left', 'centre', and 'right' refer to relative policy positions within a party; and do not refer to ideological positions that form the basis of inter-party competition.

In practice, this means that May's law is seen to apply when 'sub-leaders' (high or low) in KDU-ČSL are to the left or the right of the policy positions adopted by party voters, rank-and-file members or party leaders. According to May's law, the non-leaders (voters, rank-and-file) and leaders will have approximately the same policy positions. The question of whether the curvilinear disparity is to the 'left' or 'right' is irrelevant in this context because it is intra-party attitudinal rather than inter-party ideological differences that are being examined.

In theory, KDU-ČSL party leaders should occupy an issue position that is somewhere between the 'sub-leaders' (high and low) and the non-leaders (rank-and-file and voters). However, we will relax this assumption a little. If rank-and-file party members and leaders of KDU-ČSL have insignificant mean policy differences then May's law is said to be confirmed. This approach makes sense, as our dataset (and most party membership surveys) has an insufficient number of cases to measure party leaders' intermediate position with sufficient accuracy, due to sampling error, to be able to determine if they lie between voters and party members and sub-leaders.

May's law or curvilinear disparity has been influential because it is a parsimonious model of intra-party politics. However, most empirical tests of the special law reveal that May's simple structural model makes incorrect predictions. The general reason given for the failure to observe predicted effects is that May's [1973] general theory of opinion structure adheres to an overly simplified conception of party structure. Kitschelt [1989] attempted to overcome this problem by formulating a motivational rather than structural basis for intra-party attitudinal differences. 


\section{Application of Kitschelt's model to KDU-ČSL}

Kitschelt's [1989] 'extension' of May's law is perhaps better considered as the formulation of a rival model of intra-party politics. This is because the central questions addressed by May [1973] and Kitschelt [1989] are fundamentally different. The central question addressed by May [1973] was Butler's [1960] 'paradox' of how political parties may exist over the long-term if they are simultaneously characterised by ideological unity (vis-à-vis rival parties) and significant internal opinion and policy differences. ${ }^{10}$ His answer was that intra-party opinion differences in all parties are successfully managed via the operation of the hierarchical structure.

In contrast, Kitschelt [1989] wished to explore the interrelationship between party organisation and party systems. Adopting a context-based approach, Kitschelt felt that the internal workings of parties reflect not only the party's ideology and organisational structure but also the party system itself. Moreover, the party system was itself influenced by the nature of the parties that compose it. A key component in this process of reciprocal causation is the motivations, aspirations and behaviour of party members. For this reason, Kitschelt [1989] focused on the ideological motivations (or radicalism) of all party members, and most especially 'militants'.

As we noted earlier, Kitschelt felt that all party members regardless of their formal position in a party could be broadly defined as pragmatists or ideologues. This classification is ordinal in nature where members may range across an underlying ideologue-pragmatist motivation scale or dimension. Kitschelt [1989] used a six-point scale based on a classification of type of participation in party activities. In this study, the ideologue-pragmatist scale is not based on participation but on attitude toward whether party leaders should listen to party voters (pragmatists) or party members (ideologues).

With regard to our KDU-ČSL case study our expectations are primarily informed by Kitschelt's [1989] propositions regarding the factors that promote the entry of ideologues within a party. These expectations are presented in Table 1. The overall balance of the predictions from Table 1 is that KDU-ČSL membership will be primarily pragmatic in orientation. As all members of this party are likely to have similar policy positions curvilinear disparity is unlikely to be observed within Kitschelt's [1989] model. This is because the party organisational and party system factors within which KDU-ČSL members are embedded do not promote the emergence of 'radical middle party activists'.

\footnotetext{
${ }_{10}$ A recent study of 'ideological misfits' using party member surveys from nine parties in Belgium and Canada found no systematic difference between this minority and all other members. There are systematic differences across parties on the basis of ideology: where left-wing parties have more ideological outliers than all parties [van Haute and Carty 2011]. Such evidence suggests that a centre-right party such as KDU-ČSL is less likely to exhibit curvilinear disparity in opinions than more ideological extreme parties on the left such as the Czech Communist Party (KSČM).
} 
Table 1. Expectations regarding the application of Kitschelt's ideologue-pragmatist classification to KDU-ČSL

\begin{tabular}{|c|c|c|}
\hline No. & Prediction & $\begin{array}{c}\text { KDU-ČSL members are mainly } \\
\text { ideologues? }\end{array}$ \\
\hline 1 & $\begin{array}{l}\text { 'Pragmatists are highly interested in } \\
\text { local politics, ideologues focus on } \\
\text { national politics.' (p. 406) }\end{array}$ & $\begin{array}{l}\text { No. KDU-ČSL has a strong local } \\
\text { orientation as most of its support } \\
\text { comes from small rural communities in } \\
\text { Moravia. }\end{array}$ \\
\hline 2 & $\begin{array}{l}\text { Ideologues will predominate in a party } \\
\text { if 'the social cleavage represented by a } \\
\text { party is highly mobilized.' (p. 407) }\end{array}$ & $\begin{array}{l}\text { No. The liberal-conservative cleavage } \\
\text { represented by KDU-ČSL is not central } \\
\text { to party competition in the Czech } \\
\text { Republic. }\end{array}$ \\
\hline 3 & $\begin{array}{l}\text { Ideologues will predomin } \\
\text { if 'the existing political reg } \\
\text { little consideration to the c } \\
\text { party's main constituency. }\end{array}$ & $\begin{array}{l}\text { No. The Czech political system does } \\
\text { give consideration to the Christian } \\
\text { Democratic demands of KDU-ČSL }\end{array}$ \\
\hline 4 & $\begin{array}{l}\text { Ideologues will predominate in a party } \\
\text { if 'the party is in a weak competitive } \\
\text { position.' (p. 407) }\end{array}$ & $\begin{array}{l}\text { No. KDU-ČSL is in a strong competi- } \\
\text { tive position as it has frequently played } \\
\text { a pivotal role in coalition government } \\
\text { formation. }\end{array}$ \\
\hline 5 & $\begin{array}{l}\text { Ideologues will predominate in a party } \\
\text { if 'past moderate pragmatic party strat- } \\
\text { egies have not strengthened the party } \\
\text { organization, attracted new voters or } \\
\text { influenced public policy'. (p. 407) }\end{array}$ & $\begin{array}{l}\text { Yes and No. KDU-ČSL's pragmatic pol- } \\
\text { icy stance in successive governments } \\
\text { has been associated with influence on } \\
\text { public policy. However, it didn't attract } \\
\text { new members and voters. }\end{array}$ \\
\hline 6 & $\begin{array}{l}\text { 'The less access to middle-level posi- } \\
\text { tions is constrained, the more probable } \\
\text { is the over-representation of ideo- } \\
\text { logues.' (p. 410) }\end{array}$ & $\begin{array}{l}\text { Yes and No. Access to the middle rank- } \\
\text { ing positions in KDU-ČSL is formally } \\
\text { open but may be subject to informal } \\
\text { restrictions. }\end{array}$ \\
\hline$y$ & $\begin{array}{l}\text { 'The fewer crucial decisions are in the } \\
\text { hands of party conferences, the more } \\
\text { probable is an over-representation of } \\
\text { ideologues among the conference par- } \\
\text { ticipants.' (p. 410) }\end{array}$ & $\begin{array}{l}\text { No. Key policy decisions are not made } \\
\text { at KDU-CSL party conferences by } \\
\text { delegates but are made by the party } \\
\text { leadership }\end{array}$ \\
\hline
\end{tabular}

Source: Kitschelt [1989: 406-410].

Note: The first proposition or prediction that 'parties appeal to individuals with a wide variety of beliefs organized along a continuum of organizational, programmatic and strategic radicalism or moderation' [Kitschelt 1989: 406] is definitional. Within KDU-ČSL it was possible to find both types of party members as Kitschelt [ibid.] predicted. The evidence in the column on the right is derived from previous research [Linek and Pecháček 2006; Linek and Lyons 2008]. 


\section{Data, methodology, and operationalisation}

In this article we investigate the nature of party membership using two main sources of data: (1) a representative survey of KDU-ČSL party members (KDU-ČSL Membership Survey 2005; N = 776) and (2) a national post-election survey that contains the attitudes of KDU-ČSL party voters (Czech election study 2006; $\mathrm{N}=2002$ ). In order to test May's law previous research suggests that four criteria should be met: (a) have a systematic, valid, and reliable method for stratifying a party and possess appropriate data to implement such a stratification scheme, (b) have appropriate issue scale measurements for voters and all party members from all strata, (c) operationalise the dependent variable in a clearly defined manner, $(\mathrm{d})$ undertake attitude measurements for all major parties in a country [Kitschelt 1989: 411-418; Herrera and Taylor 1994: 677; Norris 1995: 34; Kennedy, Lyons and Fitzgerald 2006: 790]. Our research falls short in terms of the final criterion as we have data for a single party that is in electoral terms not a major party. The goal of this study is more modest as this article seeks to explore the idea that governance oriented parties will not exhibit the curvilinear disparities predicted by May [1973] or Kitschelt [1989].

\section{Stratifying a political party}

Previous research demonstrates that there is no definitive method of defining the hierarchical structure of a party. Often parties are stratified on the basis of their formal organisation. However, this approach ignores the informal nature of much party work and the importance of non-official rankings based on criteria such as whether a member was ever endorsed to represent the party in a public election. Moreover, previous studies have focused on taking a 'snapshot' of party members where current positions are used to indicate position within the party hierarchy. However, May [1973] emphasised the importance of long-term processes such as socialisation as a foundation for party stratification. Consequently, in this article we created a 'highest position ever held' hierarchy measure following a broadly similar logic to that outlined by Kitschelt [1989: 412].

Using the formal system of classification based on current status within the party aggregates most members into a single category: rank-and-file members. By adopting a 'highest position ever held' scheme a more detailed picture emerges where it is possible to reasonably disaggregate a large block of 'ordinary' party members into a more detailed schema on the basis of member's own accounts of their personal history in the party. We divided party members into four categories based on the level and intensity of their political activity. The first group consists of party members who have never been elected or appointed to any party or public office and haven't even run for any (hereafter, party member). The second group is composed of party members who have been active at the local level either within the party or as a candidate or representative in the local 
assembly (sub-leaders low). The third group (sub-leaders high) consists of party members with a district or regional party or public office and candidates for regional elections. Members of the national party bodies as well as elected representatives in national public offices and candidates make up the fourth group (leaders). The fifth category is party voters.

\section{Defining KDU-ČSL party members as pragmatists or ideologues}

An alternative means of exploring the structure of opinion within political parties is to use Kitschelt's [1989: 406] concepts of 'ideologue' and 'pragmatist'. This is based on the assumption that party members cannot be simply categorised on the basis of position. Party members in all strata are likely to exhibit 'diverse motivations and aspirations.' However, despite such attitudinal heterogeneity Kitschelt [1989] argued that party members should exhibit one of two general ideological orientations. Pragmatists are primarily office seeking in motivation, and therefore prefer centrist issue positions. In contrast, ideologues are more policy driven and are motivated to serve the party's core constituency and promote radical party platforms, regardless if this reduces the party's electoral competitiveness. Here because of data limitations we will use a single indicator of ideological diversity within KDU-ČSL. Respondents who definitely agreed with the statement: 'party leaders should listen more to party voters than to party members' were defined as pragmatists. In contrast, ideologues are those who definitely disagree with this statement, while those who selected 'agree' or 'disagree' are assumed to have intermediate orientations. Our party membership survey reveals that $15 \%$ of the respondents gave a strong pragmatist answer, in contrast to $4 \%$ of members who may be defined as strong ideologues. The remaining eight in ten of those interviewed adopted a centrist position on our pragmatist-ideologue scale.

\section{Dependent variables—issue scales}

The central question examined in this article is: what is the substantive opinion structure within KDU-ČSL? In order to answer this question a total of eleven issue scales will be examined. These issue scales refer to the two main cleavages within Czech politics, i.e. economic dimension (left-right, state regulation of the economy, size of the public sector, priority of economy vs environment, progressive vs flat tax regime, state or private provision of public services, and state aid to farmers), and liberal-conservative dimension (abortion, asylum and migration, security vs civil liberties aspects of crime policy). Moreover, we add a scale measuring the support for more European integration. To measure party members' attitudes on these issues, ten-point issue scales were asked to a representative sample of KDU-ČSL members in the summer of 2005. Similar data was gathered a year later in a post-election survey for voters of this party (the wording of ques- 
tions is presented in Appendix 1). ${ }^{11}$ These issue scales provide enough substantive issues to explore May's law. Moreover, they don't measure general values or ideological orientations except for the left-right scale and perhaps abortion (social liberal-conservatism).

\section{Analysis}

\section{Relationship between issue position and party stratification}

In order to examine the central theme in May's law a comparison of party members and voter's positions on our eleven issue scales was undertaken. The results of a comparison of means analysis for all five party strata across eleven issue scales are reported in Table 2. An examination of these results reveals that for some economic issues such as taxation and state aid to farmers there is some evidence supportive of May's special law of curvilinear disparity. In all four cases, KDU-ČSL party members and the lower echelons of sub-leaders exhibit more extreme opinions than either high-ranking party members or voters. Moreover, a stratum of members is significantly to the left (of centre) of all other members on three socioeconomic issues. Earlier it was noted that although KDU-ČSL advocates for a social market economy, making it centre right; it also supports policies of economic redistribution by the state in society. This 'corporatist' pattern undoubtedly stems from the party's Christian socialist and trade-unionist roots, and interest in creating greater equality in society.

For the remaining seven issue areas, party leaders are more rightist than the rest of the party on five issues: size of the public sector, abortion, state intervention into the economy, European integration, and left-right; and centrist on two issues: immigration and provision of public services. These differences may be interpreted as reflecting an office-seeking or pragmatic orientation on the part of party leaders. These issue specific patterns represent a 'new twist' on May's law because it suggests that it is not always possible, or even meaningful, to evaluate the ideological orientation of a party in terms of a single dimension as May [1973: 139] assumed in his special curvilinear disparity model.

The evidence presented here illustrates patterns consonant with some of May's other four (curvilinear and non-curvilinear) models of intra-party opinion differences that have been reported by previous researchers [McCloskey, Hoffmann and O'Hara 1960; Constantini 1963; Rose 1974; Searing 1986; Narud and Skare 1999]. In short, special curvilinear disparity patterns in party members' opinions are likely to be issue specific, rather than have general application. We will however refrain from making a final judgement on this question until we present results from a more generalised attitudinal analysis a little later.

${ }^{11}$ For comparison between the 10-point party membership issue scales and the 11-point party voter ones, the latter were re-scaled to 10-point scales. 
Turning our attention now to Kitschelt's [1989] ideologue and pragmatist concepts we expect that in KDU-ČSL ideologues are more likely to hold sub-leader positions and pragmatists are likely to be concentrated among the sub-leader high or leadership strata. The membership survey data results provide only limited evidence for these expectations. On the basis of KDU-ČSL's ideology, party organisation, and the nature of the Czech party system (see Table 1) it is not surprising to find that both ordinary members and leaders were more likely to give responses indicative of a pragmatist orientation (62\% and $57 \%$, respectively). In addition, both low and high sub-leader strata were also more likely to give pragmatist responses (59\% and 52\%, respectively). Such evidence suggests that the ideologue/pragmatism indicator is not strongly correlated with position in the party.

The results presented in Table 3 reveal that only with regard to the issue of abortion does the pattern in the data match with Kitschelt's expectations. For a majority of issues dealing mainly with economic concerns the opinions of voters, ideologues, and pragmatists are statistically indistinguishable. In a further two issue domains (state aid to farmers and immigration) ideologues and pragmatists are similar in being both extreme and significantly different from their centrist co-partisan voters. And finally with regard to the provision of public services and the security vs civil liberties aspects of crime policy, it is pragmatists who exhibit the most extreme opinions.

In summary, our expectations deriving from Kitschelt's [1989] concepts of pragmatists and ideologues are only met in the case of abortion. This is significant as this is a core issue for a Christian Democratic party whose heartland is based in a traditional, largely rural Catholic region of the Czech Republic, i.e. Moravia. However, our party members survey asked respondents to indicate on a $0-10$ point scale the importance of all issues examined in Tables 1 and 2 (except left-right). The results reveal that abortion is not the most important issue for KDU-CSL party members. Although abortion is a core issue for Christian Democrats' identity it is not an important issue for party members. Abortion is supported by the vast majority of the Czech electorate and it does not constitute the basis for party competition in elections. As in our evaluation of the evidence for May's law we find only limited support for Kitchelt's expectations.

\section{Relative importance of stratification and sociodemographic attributes}

It was noted earlier that May [1973] in the third part of his article outlined what he considered were the 'foundations of curvilinear disparity'. In this respect, he emphasised the importance of (a) party recruitment practices stemming from membership of social networks, (b) selective screening of members into specific party strata on basis of characteristics such as class, (c) regional political variables stemming from sociodemographic characteristics and electoral history. Alternatively, one might simply argue that party members issue positions are not 
Table 2. Comparison of mean positions of KDU-ČSL voters, members, sub-leaders, and leaders on various issue scales (1-10)

\begin{tabular}{|c|c|c|c|c|}
\hline Issues and position & Mean & $\mathrm{SD}$ & $\mathrm{N}$ & Notes \\
\hline Taxation regime & & & & $(1=$ progressive, $10=$ flat tax $)$ \\
\hline Voter & 4.0 & 2.8 & 82 & \multirow{5}{*}{$\begin{array}{l}\text { Fits May's law: party members and } \\
\text { some sub-leaders are more extreme } \\
\text { than either voters or leaders. No sig- } \\
\text { nificant difference between voters and } \\
\text { leaders (and sub-leaders high) }\end{array}$} \\
\hline Party member & $3.0^{\mathrm{bc}}$ & 2.3 & 254 & \\
\hline Sub-leader low & $3.1^{\mathrm{a}}$ & 2.6 & 277 & \\
\hline Sub-leader high & $4.0^{\mathrm{b}}$ & 2.8 & 118 & \\
\hline Leader & $4.4^{c}$ & 2.3 & 77 & \\
\hline Farm subsidies & & & & \multirow[t]{2}{*}{$(1=$ yes, $10=$ no $)$} \\
\hline Voter & 3.8 & 2.2 & 84 & \\
\hline Party member & $2.8^{\mathrm{bc}}$ & 2.1 & 259 & \multirow{4}{*}{$\begin{array}{l}\text { Fits May's law: party members and } \\
\text { some sub-leaders are more extreme } \\
\text { than either voters or leaders. No sig- } \\
\text { nificant difference between voters and } \\
\text { leaders (and sub-leaders high) }\end{array}$} \\
\hline Sub-leader low & $2.9^{\mathrm{a}}$ & 2.1 & 280 & \\
\hline Sub-leader high & $3.6^{b}$ & 2.2 & 118 & \\
\hline Leader & $4.1^{c}$ & 2.0 & 77 & \\
\hline $\begin{array}{l}\text { Crime: security ws } \\
\text { civil liberties }\end{array}$ & & & & \multirow[t]{2}{*}{ ( 1 = security, 10 = civil liberties $)$} \\
\hline Voter & 5.0 & 3.2 & 86 & \\
\hline Party member & $6.1^{\mathrm{bc}}$ & 3.3 & 255 & \multirow{4}{*}{$\begin{array}{l}\text { Fits May's law: party members and } \\
\text { some sub-leaders are more extreme } \\
\text { than either voters or leaders. No sig- } \\
\text { nificant difference between voters and } \\
\text { leaders (and sub-leaders high) }\end{array}$} \\
\hline Sub-leader low & $5.8^{\mathrm{a}}$ & 3.4 & 277 & \\
\hline Sub-leader high & $5.2^{b}$ & 3.0 & 116 & \\
\hline Leader & $4.7^{\mathrm{c}}$ & 2.4 & 77 & \\
\hline $\begin{array}{l}\text { Economy and } \\
\text { environment }\end{array}$ & & & & \multirow[t]{2}{*}{$(1=$ environment, $10=$ economy $)$} \\
\hline Voter & 4.5 & 2.0 & 82 & \\
\hline Party member & $3.9^{\mathrm{abc}}$ & 2.3 & 253 & \multirow{4}{*}{$\begin{array}{l}\text { Fits May's law (partially): party mem- } \\
\text { bers are more extreme than voters, } \\
\text { sub-leaders or leaders. No significant } \\
\text { difference between voters, sub-leaders } \\
\text { and leaders }\end{array}$} \\
\hline Sub-leader low & $4.3^{\mathrm{a}}$ & 2.3 & 278 & \\
\hline Sub-leader high & $4.6^{b}$ & 2.0 & 116 & \\
\hline Leader & $4.8^{c}$ & 1.9 & 77 & \\
\hline Immigration & & & & \multirow[t]{2}{*}{$(1=$ more strict laws, $10=$ less strict laws $)$} \\
\hline Voter & 2.9 & 2.1 & 80 & \\
\hline Party member & $3.9^{\mathrm{bc}}$ & 2.4 & 254 & \multirow{4}{*}{$\begin{array}{l}\text { Does not fit May's law: leaders are more } \\
\text { centrist than either members, sub-lead- } \\
\text { ers, or voters }\end{array}$} \\
\hline Sub-leader low & $3.9^{\mathrm{a}}$ & 2.3 & 277 & \\
\hline Sub-leader high & $4.7^{b}$ & 2.1 & 115 & \\
\hline Leader & $5.2^{\mathrm{c}}$ & 2.1 & 74 & \\
\hline
\end{tabular}


Table 2. Comparison of mean positions of KDU-ČSL voters, members, sub-leaders, and leaders on various issue scales (1-10)—continued

\begin{tabular}{|c|c|c|c|c|}
\hline Issues and position & Mean & SD & $\mathrm{N}$ & Notes \\
\hline $\begin{array}{l}\text { Provision of public } \\
\text { services }\end{array}$ & & & & $(1=$ state, $10=$ self $)$ \\
\hline Voter & 3.9 & 2.0 & 87 & \multirow{5}{*}{$\begin{array}{l}\text { Does not fit May's law: leaders are more } \\
\text { centrist than either members, sub-lead- } \\
\text { ers or voters }\end{array}$} \\
\hline Party member & $3.1^{\mathrm{bc}}$ & 2.2 & 260 & \\
\hline Sub-leader low & $3.3^{\mathrm{a}}$ & 2.3 & 277 & \\
\hline Sub-leader high & $4.0^{\mathrm{b}}$ & 2.2 & 115 & \\
\hline Leader & $5.4^{c}$ & 2.1 & 77 & \\
\hline Abortion & & & & $(1=$ woman's choice, $10=$ ban $)$ \\
\hline Voter & 6.0 & 3.6 & 82 & \multirow{5}{*}{$\begin{array}{l}\text { Does not fit May's law: party members } \\
\text { at all levels have similar opinions, lead- } \\
\text { ers and other party members are more } \\
\text { extreme than voters }\end{array}$} \\
\hline Party member & 7.0 & 3.4 & 253 & \\
\hline Sub-leader low & $6.9^{\mathrm{a}}$ & 3.3 & 273 & \\
\hline Sub-leader high & $6.9^{\mathrm{b}}$ & 2.9 & 115 & \\
\hline Leader & $6.9^{c}$ & 2.4 & 76 & \\
\hline Size of public sector & & & & ( $1=$ large, $10=$ small $)$ \\
\hline Voter & 5.1 & 2.4 & 77 & \multirow{5}{*}{$\begin{array}{l}\text { Does not fit May's law: leaders are more } \\
\text { extreme than either members, sub-lead- } \\
\text { ers, or voters }\end{array}$} \\
\hline Party member & $5.9^{\mathrm{bc}}$ & 2.6 & 222 & \\
\hline Sub-leader low & $6.1^{\mathrm{a}}$ & 2.5 & 268 & \\
\hline Sub-leader high & $6.4^{\mathrm{b}}$ & 2.2 & 113 & \\
\hline Leader & $7.3^{c}$ & 1.8 & 77 & \\
\hline $\begin{array}{l}\text { State regulation } \\
\text { of economy }\end{array}$ & & & & \multirow{6}{*}{$\begin{array}{l}\text { Does not fit May's law: leaders are more } \\
\text { extreme than either members, sub-lead- } \\
\text { ers, or voters }\end{array}$} \\
\hline Voter & 4.6 & 2.2 & 74 & \\
\hline Party member & $4.7^{\mathrm{bc}}$ & 2.4 & 245 & \\
\hline Sub-leader low & $5.1^{\mathrm{a}}$ & 2.6 & 274 & \\
\hline Sub-leader high & $5.7^{b}$ & 2.5 & 115 & \\
\hline Leader & $6.9^{c}$ & 1.9 & 76 & \\
\hline Left-right & & & & \multirow[t]{2}{*}{$(1=$ left, $10=$ right $)$} \\
\hline Voter & 5.6 & 1.5 & 83 & \\
\hline Party member & $7.6^{\mathrm{abc}}$ & 1.9 & 227 & \multirow{4}{*}{$\begin{array}{l}\text { Does not fit May's law: leaders and } \\
\text { voters have significantly different posi- } \\
\text { tions. However, there is evidence of } \\
\text { general curvilinear disparity }\end{array}$} \\
\hline Sub-leader low & $7.1^{\mathrm{a}}$ & 2.1 & 268 & \\
\hline Sub-leader high & $7.2^{b}$ & 1.4 & 110 & \\
\hline Leader & $6.9^{c}$ & 1.2 & 76 & \\
\hline
\end{tabular}


Table 2. Comparison of mean positions of KDU-ČSL voters, members, sub-leaders, and leaders on various issue scales (1-10)—continued

\begin{tabular}{lccrl}
\hline Issues and position & Mean & SD & N & \multicolumn{1}{c}{ Notes } \\
\hline European integration & & & & \\
Voter & 4.4 & 2.3 & 68 & \\
Party member & $\mathbf{6 . 1}^{\text {bc }}$ & 2.5 & 237 & Does not fit May's law: leaders are more \\
Sub-leader low & $\mathbf{6 . 5}^{\text {a }}$ & 2.6 & 271 & extreme than either members, sub-lead- \\
Sub-leader high & $\mathbf{6 . 8}^{\mathrm{b}}$ & 1.9 & 112 & ers, or voters \\
Leader & $\mathbf{7 . 0}^{\mathrm{c}}$ & 1.9 & 77 & \\
\hline
\end{tabular}

Source: KDU-ČSL Membership Survey 2005 (data weighted to reflect the regional distribution of overall party membership); Czech Election Study 2006.

Note: The differences in policy positions in this table are reported in two distinct ways. First, the mean estimates in bold indicate significant differences in the mean $(\mathrm{p} \leq .05)$ between voters and party members (at various levels). Thus, for example in the case of the left-right scale all strata within KDU-ČSL have mean scores that are significantly different from those of Christian Democratic voters. Second, mean differences within the KDU-ČSL party are indicated through superscripts. The focus here is on intraparty differences because Kitschelt [1989] unlike May [1973] excluded party voters from consideration. Therefore, in order to compare May [1973] and Kitchelt's [1989] models it is necessary to restrict attention to those who are formally members of KDU-CSL. In all differences of means tests, the base or comparison group is party member. The higher echelons are identified by superscripts, i.e. (a) sub-leader low, (b) sub-leader high, and (c) leaders. This labelling is shown for all scales in this table. The data should be interpreted as follows. For the left-right scale the superscripts $\mathrm{a}, \mathrm{b}$, and $\mathrm{c}$ for party members indicate that the mean score of 7.6 is significantly different $(\mathrm{p} \leq .05)$ for sub-leaders low, sub-leaders high, and leaders. With the European integration scale, the superscripts $b$ and $c$ for party members indicate significant mean differences between party members and high sub-leaders and leaders. Some of the scales were transformed so that 1 means leftist preferences and 10 rightist preferences. 
Table 3. Comparison of mean positions of KDU-ČSL voters, ideologues, and pragmatists on various issue scales (1-10)

\begin{tabular}{|c|c|c|c|c|}
\hline Issues and orientation & Mean & $\mathrm{SD}$ & $\mathrm{N}$ & Notes \\
\hline Abortion & & & & ( 1 = woman's choice, 10 = ban $)$ \\
\hline Voter & 6.0 & 3.6 & 82 & \multirow{5}{*}{$\begin{array}{l}\text { Fits with Kitschelt [1989]: vot- } \\
\text { ers and pragmatists are simi- } \\
\text { lar and both are significantly } \\
\text { different from ideologues }\end{array}$} \\
\hline Definitely agree (pragmatist) & $5.4^{\mathrm{abc}}$ & 3.5 & 114 & \\
\hline Agree & $6.7^{\mathrm{a}}$ & 3.4 & 250 & \\
\hline Disagree & $8.0^{\mathrm{b}}$ & 2.6 & 243 & \\
\hline Definitely disagree (ideologue) & $8.4^{c}$ & 2.1 & 31 & \\
\hline Taxation regime & & & & \multirow[t]{2}{*}{$(1=$ progressive, $10=$ flat tax $)$} \\
\hline Voter & 4.0 & 2.8 & 82 & \\
\hline Definitely agre & 3.4 & 2.9 & 117 & \multirow{4}{*}{$\begin{array}{l}\text { Does not fit with Kitschelt } \\
\text { [1989]: ideologues and prag- } \\
\text { matists have similar issue } \\
\text { positions and are significantly } \\
\text { different from voters }\end{array}$} \\
\hline Agree & $3.1^{\mathrm{a}}$ & 2.5 & 250 & \\
\hline Disagree & $3.3^{b}$ & 2.4 & 249 & \\
\hline Definitely disagree (ideologue) & $3.0^{c}$ & 2.7 & 32 & \\
\hline Size of public sector & & & & \multirow[t]{2}{*}{$(1=$ large, $10=$ small $)$} \\
\hline Voter & 5.1 & 2.4 & 77 & \\
\hline Definitely agree (pragmatist) & $5.7^{b}$ & 2.8 & 117 & \multirow{4}{*}{$\begin{array}{l}\text { Does not fit with Kitschelt } \\
\text { [1989]: ideologues and prag- } \\
\text { matists have similar issue po- } \\
\text { sition and are not significantly } \\
\text { different from voters }\end{array}$} \\
\hline Agree & $6.0^{\mathrm{a}}$ & 2.7 & 237 & \\
\hline Disagree & $6.4^{\mathrm{b}}$ & 1.9 & 231 & \\
\hline Definitely disagree (ideologue) & $6.1^{\mathrm{c}}$ & 3.0 & 32 & \\
\hline Economy and environment & & & & \multirow[t]{2}{*}{$(1$ = environment, $10=$ economy $)$} \\
\hline Voter & 4.5 & 2.0 & 82 & \\
\hline Definitely agree (pragmatist) & $4.7^{\mathrm{ab}}$ & 2.5 & 118 & \multirow{4}{*}{$\begin{array}{l}\text { Does not fit with Kitschelt } \\
\text { [1989]: ideologues and prag- } \\
\text { matists have similar issue } \\
\text { positions and are not signifi- } \\
\text { cantly different from voters }\end{array}$} \\
\hline Agree & $3.9^{\mathrm{a}}$ & 2.4 & 250 & \\
\hline Disagree & $4.2^{\mathrm{b}}$ & 2.0 & 249 & \\
\hline Definitely disagree (ideologue) & $4.9^{c}$ & 2.9 & 32 & \\
\hline State regulation of economy & & & & $(1=\max , 10=\min )$ \\
\hline Voter & 4.6 & 2.4 & 77 & \multirow{5}{*}{$\begin{array}{l}\text { Does not fit with Kitschelt } \\
\text { [1989]: ideologues and prag- } \\
\text { matists have similar issue } \\
\text { positions and are not signifi- } \\
\text { cantly different from voters }\end{array}$} \\
\hline Definitely agree (pragmatist) & $4.8^{\mathrm{b}}$ & 2.8 & 117 & \\
\hline Agree & $4.9^{\mathrm{a}}$ & 2.7 & 237 & \\
\hline Disagree & $5.2^{\mathrm{b}}$ & 1.9 & 231 & \\
\hline Definitely disagree (ideologue) & $5.1^{c}$ & 3.0 & 32 & \\
\hline
\end{tabular}


Table 3. Comparison of mean positions of KDU-ČSL voters, ideologues, and pragmatists on various issue scales (1-10)—continued

\begin{tabular}{|c|c|c|c|c|}
\hline Issues and orientation & Mean & SD & $\mathrm{N}$ & Notes \\
\hline Left-right & & & & $(1=$ left, $10=$ right $)$ \\
\hline Voter & 5.6 & 1.5 & 83 & \multirow{5}{*}{$\begin{array}{l}\text { Does not fit with Kitschelt } \\
\text { [1989]: ideologues and prag- } \\
\text { matists have similar issue } \\
\text { positions and are significantly } \\
\text { different from voters }\end{array}$} \\
\hline Definitely agree (pragmatist) & 7.2 & 2.4 & 102 & \\
\hline Agree & $7.3^{\mathrm{a}}$ & 2.1 & 242 & \\
\hline Disagree & $7.2^{\mathrm{b}}$ & 1.7 & 228 & \\
\hline Definitely disagree (ideologue) & $7.6^{c}$ & 1.8 & 31 & \\
\hline European integration & & & & \multirow[t]{2}{*}{$(1=$ less, $10=$ more $)$} \\
\hline Voter & 4.4 & 2.3 & 68 & \\
\hline Definitely agree (pragmatist) & 6.0 & 2.9 & 111 & \multirow{4}{*}{$\begin{array}{l}\text { Does not fit with Kitschelt } \\
\text { [1989]: ideologues and prag- } \\
\text { matists have similar issue } \\
\text { positions and are significantly } \\
\text { different from voters }\end{array}$} \\
\hline Agree & $6.4^{\mathrm{a}}$ & 2.5 & 242 & \\
\hline Disagree & $6.5^{\mathrm{b}}$ & 2.1 & 245 & \\
\hline Definitely disagree (ideologue) & $6.4^{c}$ & 2.9 & 32 & \\
\hline Immigration & & & & $\begin{array}{c}(1=\text { more strict laws, } \\
10=\text { less strict laws })\end{array}$ \\
\hline Voter & 2.9 & 2.1 & 80 & \multirow{5}{*}{$\begin{array}{l}\text { Does not fit with Kitschelt } \\
\text { [1989]: ideologues and prag- } \\
\text { matists have similar issue } \\
\text { positions and are significantly } \\
\text { different from voters }\end{array}$} \\
\hline Definitely agree (pragmatist) & $3.8^{\mathrm{b}}$ & 2.6 & 119 & \\
\hline Agree & $4.0^{\mathrm{a}}$ & 2.6 & 247 & \\
\hline Disagree & $4.3^{\mathrm{b}}$ & 2.0 & 247 & \\
\hline Definitely disagree (ideologue) & $3.8^{c}$ & 2.4 & 31 & \\
\hline Farm subsidies & & & & \multirow[t]{2}{*}{$(1=$ yes, $10=$ no $)$} \\
\hline Voter & 3.8 & 2.2 & 84 & \\
\hline Definitely agree (pragmatist) & 3.0 & 2.4 & 118 & \multirow{4}{*}{$\begin{array}{l}\text { Does not fit with Kitschelt } \\
\text { [1989]: ideologues and prag- } \\
\text { matists have similar issue } \\
\text { positions and are significantly } \\
\text { different from voters }\end{array}$} \\
\hline Agree & $2.8^{\mathrm{a}}$ & 2.0 & 253 & \\
\hline Disagree & $3.2^{b}$ & 2.0 & 249 & \\
\hline Definitely disagree (ideologue) & $3.2^{\mathrm{c}}$ & 2.6 & 32 & \\
\hline Provision of public services & & & & $(1=$ state, $10=$ self $)$ \\
\hline Voter & 3.9 & 2.0 & 87 & \multirow{5}{*}{$\begin{array}{l}\text { Does not fit with Kitschelt } \\
\text { [1989]: no significant differ- } \\
\text { ences between ideologues and } \\
\text { voters; pragmatists are more } \\
\text { extreme than ideologues or } \\
\text { voters }\end{array}$} \\
\hline Definitely agree (pragmatist) & $2.7^{\mathrm{ab}}$ & 2.1 & 119 & \\
\hline Agree & $3.2^{\mathrm{a}}$ & 2.3 & 257 & \\
\hline Disagree & $3.8^{b}$ & 2.0 & 248 & \\
\hline Definitely disagree (ideologue) & $3.3^{c}$ & 2.9 & 32 & \\
\hline
\end{tabular}


Table 3. Comparison of mean positions of KDU-ČSL voters, ideologues, and pragmatists on various issue scales (1-10)—continued

\begin{tabular}{|c|c|c|c|c|}
\hline Issues and orientation & Mean & SD & $\mathrm{N}$ & Notes \\
\hline $\begin{array}{l}\text { Crime: security vs } \\
\text { civil liberties }\end{array}$ & & & & $\begin{array}{c}(1=\text { security, } \\
10=\text { civil liberties })\end{array}$ \\
\hline Voter & 5.0 & 3.2 & 86 & \multirow{5}{*}{$\begin{array}{l}\text { Does not fit with Kitschelt } \\
\text { [1989]: no significant differ- } \\
\text { ences between ideologues and } \\
\text { voters; pragmatists are more } \\
\text { extreme than ideologues or } \\
\text { voters }\end{array}$} \\
\hline Definitely agree (pragmatist) & $6.1^{b}$ & 3.6 & 121 & \\
\hline Agree & $6.0^{\mathrm{a}}$ & 3.4 & 251 & \\
\hline Disagree & $5.4^{\mathrm{b}}$ & 2.9 & 247 & \\
\hline Definitely disagree (ideologue) & $5.7^{c}$ & 3.9 & 32 & \\
\hline
\end{tabular}

Source: KDU-ČSL Membership Survey 2005 (data weighted to reflect the regional distribution of overall party membership); Czech Election Study 2006.

Note: Pragmatists and ideologues are defined in terms of response to the statement 'Party leaders should listen more to party voters [1: pragmatists] rather than party members [4: ideologues]'. Those who definitely agreed with the statement are pragmatists, while those who definitely disagreed are ideologues. Intermediate responses such as agree or disagree are 'mixed'. The differences in policy positions reported in this table are reported in two distinct ways. First, the mean estimates in bold indicate significant differences in the mean $(\mathrm{p} \leq .05)$ between voters and ideologues (at various levels). Thus, for the left-right scale all strata within KDU-ČSL have mean scores that are significantly different from those of Christian Democratic voters. Second, mean differences within the KDU-ČSL party are indicated through superscripts. In all differences of means tests, the base or comparison group is pragmatist. The more ideologically oriented members are identified by superscripts, i.e. (a) agree with pragmatist statement, (b) disagree with pragmatist statement, and (c) strongly disagree with pragmatist statement. This labelling is shown for all scales in this table. The data should be interpreted as follows. For the abortion scale the superscripts $a, b$, and c for pragmatists indicate that the mean score of 5.4 is significantly different ( $\mathrm{p} \leq .05$ ) for all levels of ideologue, i.e. 'agree', 'disagree', and 'strongly disagree'. Some of the scales were transformed so that 1 means leftist preferences and 10 rightist preferences. 
Table 4. Regression models of selected policy positions using May's classification of KDU-ČSL party members

\begin{tabular}{|c|c|c|c|c|c|c|}
\hline \multirow{3}{*}{ Variables } & \multicolumn{6}{|c|}{ May's law of curvilinear disparity } \\
\hline & \multicolumn{2}{|c|}{ 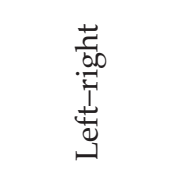 } & \multicolumn{2}{|c|}{ 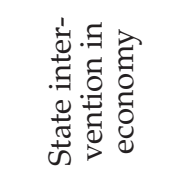 } & \multicolumn{2}{|c|}{ 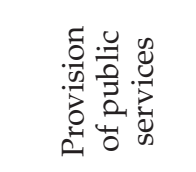 } \\
\hline & B & SE & B & SE & B & SE \\
\hline Party member & -.02 & .24 & -.47 & .31 & .34 & .28 \\
\hline Sub-leader low & -.43 & .23 & -.24 & .30 & .24 & .27 \\
\hline Leader & -.20 & .29 & .80 & .38 & -1.06 & .34 \\
\hline Age (x 10 years) & .04 & .06 & -.09 & .08 & .14 & .07 \\
\hline Education & -.19 & .09 & .43 & .11 & -.37 & .10 \\
\hline $\begin{array}{l}\text { Bohemia vs } \\
\text { Moravia }\end{array}$ & .42 & .15 & -.41 & .20 & .19 & .18 \\
\hline Old/new member & -.17 & .17 & -.41 & .22 & -.15 & .19 \\
\hline Family member & -.06 & .16 & -.29 & .21 & -.14 & .18 \\
\hline Intercept & 7.35 & .59 & 6.29 & .77 & 7.59 & .69 \\
\hline $\mathrm{R}$ & .22 & & .33 & & .36 & \\
\hline R Square & .05 & & .11 & & .13 & \\
\hline Adj. R square & .03 & & .10 & & .12 & \\
\hline SE of Est. & 1.78 & & 2.38 & & 2.15 & \\
\hline $\mathrm{N}$ & 561 & & 587 & & 604 & \\
\hline
\end{tabular}

Source: KDU-ČSL Membership Survey 2005.

Note: Coefficients in bold are significant $(\mathrm{p} \leq .05)$. OLS regression analyses based on unweighted data. The issues selected for this table are those that 'fit' with May's law as shown earlier in Table 2. Left-right orientation is included in the regression models to demonstrate that curvilinear disparity is not evident for a key general ideological orientation. 
Table 5. Regression models of selected policy positions using Kitschelt's classification of KDU-ČSL party members

\begin{tabular}{|c|c|c|c|c|c|c|c|c|}
\hline \multirow{3}{*}{ Variables } & \multicolumn{8}{|c|}{ Kitschelt's ideologues and pragmatists } \\
\hline & \multicolumn{2}{|c|}{ 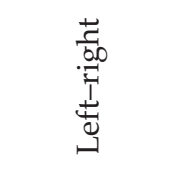 } & \multicolumn{2}{|c|}{ 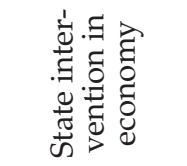 } & \multicolumn{2}{|c|}{ 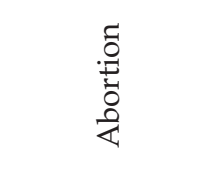 } & \multicolumn{2}{|c|}{ 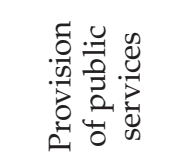 } \\
\hline & $\mathrm{B}$ & SE & $\mathrm{B}$ & SE & B & SE & $\mathrm{B}$ & SE \\
\hline Strong pragmatist & -.17 & .22 & -.61 & .29 & 1.27 & .37 & .67 & .26 \\
\hline Mild ideologue & -.09 & .17 & -.02 & .23 & -1.35 & .28 & -.20 & .20 \\
\hline Strong ideologue & .36 & .40 & -.02 & .52 & -1.44 & .65 & .52 & .46 \\
\hline Age (x 10 years) & .03 & .06 & -.12 & .08 & -.16 & .10 & .15 & .07 \\
\hline Education & -.20 & .08 & .56 & .10 & -.06 & .13 & -.49 & .09 \\
\hline $\begin{array}{l}\text { Bohemia vs } \\
\text { Moravia }\end{array}$ & .39 & .16 & -.44 & .20 & -.75 & .25 & .24 & .18 \\
\hline Old/new member & -.18 & .17 & -.46 & .22 & .17 & .27 & -.12 & .19 \\
\hline Family member & -.05 & .16 & -.26 & .21 & -.22 & .26 & -.17 & .18 \\
\hline Intercept & 7.33 & .58 & 6.14 & .76 & 6.34 & .95 & 7.74 & .68 \\
\hline $\mathrm{R}$ & .20 & & .32 & & .32 & & .35 & \\
\hline R Square & .04 & & .10 & & .10 & & .12 & \\
\hline Adj. R square & .03 & & .09 & & .09 & & .11 & \\
\hline SE of Est. & 1.79 & & 2.39 & & 3.01 & & 2.16 & \\
\hline $\mathrm{N}$ & 561 & & 587 & & 594 & & 604 & \\
\hline
\end{tabular}

Source: KDU-ČSL Membership Survey 2005.

Note: Coefficients in bold are significant $(\mathrm{p} \leq .05)$. OLS regression analyses are based on unweighted data. The issues selected for this table include abortion which fitted with Kitschelt's model in Table 3 and those other issues that illustrated significant party member classification effects. Left-right orientation is included in the Kitschelt regression models to demonstrate that curvilinear disparity is not evident for a key general ideological orientation. 
determined by position within the party hierarchy or general ideological orientation as specified by Kitschelt [1989]. Issue positions are more directly shaped by attributes associated with the sociodemographic characteristics of party members and voters.

We will not investigate in this article if sociodemographic variables directly determine issue positions, or if position within a party mediates the impact of sociodemographics characteristics. Here we will simply test whether position within the KDU-ČSL or ideologue/pragmatist orientation play a greater role in explaining variation in party members issue positions than a small set of sociodemographic items. The sociodemographic variables used in our series of ordinary least squares (OLS) regression models are age, education, region of residence, period when joined the party, and family membership.

The age variable captures features of a respondent's political socialisation and also their current economic status, e.g. pensioner-the mean age for KDU-ČSL members is 63 years in our data file. Education will be used here as a potential proxy for selective recruitment as most senior KDU-ČSL members have a high level of schooling. Regional political differences are captured by a simple Bohemia vs Moravia variable. These two regions have distinct histories, socio-political cultures and levels of economic wealth. The qualitative difference of party membership under communism and thereafter is measured using a sim$\mathrm{ple}$ 'old/new member' dummy variable where the cut point is party membership before and after 1989. However, there is a correlation between age and old/new member dummy variable as those who joined the party before 1989 have the average age of 68 years whereas those who joined the party later have 60 years on average. Finally, our 'family member' measure captures the degree to which the respondent's primary social network—the family-is integrated into KDU-ČSL. In the past, such social networks were the principal source of recruitment.

Regression models were run for all eleven issue scales. All models were estimated using either party stratification variable or ideologue/pragmatist variable. Thus, 24 models were estimated. Only those five models that exhibit significant coefficients for the classification of party members according to May [1973] or Kitschelt [1989] are presented in Table 4 and 5 respectively. Two additional models are included because they refer to left-right self-placement-the only general ideological orientation examined in this study. All of the regression results are available in Appendix 2.

One of the key findings in Table 4 is that positions within the KDU-ČSL party hierarchy are only important for predicting policy positions relating to state regulation of the economy and provision of public services. Another key finding is that none of the four policy scales that concurred with the expectations from May's law shown earlier in Table 2 exhibit the expected statistically significant effects (not shown in Table 4). Inspection of the sociodemographic variables in the bottom part of Table 4 reveals that education has the most consistent effect, with the sign of the model coefficients being issue specific. Moreover, age and 
region variables are also significant in explaining variance for a smaller subset of issues.

A broadly similar pattern is observed in Table 5 where there is an examination of how well Kitchelt's [1989] ideologue and pragmatist variables predict the issue positions of members in contrast to their sociodemographic characteristics. The most striking feature of this set of models are the coefficients for attitudes towards abortion. These results reveal that ideological orientation is very important, as is whether a party member lives in (Catholic) Moravia in predicting KDU-ČSL members' attitudes on this core party issue.

Nonetheless, the bulk of the evidence in Tables 4 and 5 demonstrates that (with the notable exception of abortion) KDU-ČSL members' position in their party matters less than sociodemographic profile in explaining the opinion structure within KDU-ČSL. Perhaps the most revealing feature of the regression models estimated are the limited number of issue domains where party position and ideological orientation matter. In essence, it would seem May's law and Kitschelt's extension of May's work only apply to issues of abortion, state regulation of the economy, and provision of public services.

\section{Conclusion}

The representation and responsibility functions of parliamentary governments are becoming increasingly incompatible because governing parties now mediate between the state and citizen, rather than representing the citizen within state institutions [Mair 2009]. This reversal of roles is especially evident in the current Eurozone crisis where external constraints rather than domestic considerations have brought down governing parties in Ireland, Portugal, Slovakia, and Spain. Moreover, the installation of technocratic governments in Greece and Italy demonstrates how the external constraints imposed on (ir)responsible governments are undermining the process of political representation via elections.

Mair [2011] has argued that the weakening of political parties will result in (a) 'democracy without choices' because no party effectively represents citizens' domestic interests, or (b) the emergence of populist parties and governments that eschew responsibility. The growing inability of mainstream governing parties to balance their representative and governance roles is according to Mair [2009] creating a 'democratic malaise'. The growing weakness of parties is in turn attributed to declining partisanship, falling party membership, and growing distrust in political parties, parliaments and governments. Political parties also face a fragmented public opinion, increased electoral volatility, and the loss of social anchors making political representation ever more difficult. The goal of this article has been to examine the intra-party foundations of this democratic malaise.

Our descriptive analyses demonstrate that May's special law of curvilinear disparity only exists to a very limited degree in KDU-ČSL. We observe this spe- 
cial pattern in about a third of all issue domains examined-a similar proportion to that found by Narud and Skare [1999] in Norway. With regard to Kitschelt's expectations of finding significant attitudinal differences on the basis of having an ideologue rather than pragmatist orientation, we were less successful, as only one single issue-abortion-exhibited the predicted pattern. Extending these analyses through use of regression modelling where account is taken of the position of KDU-ČSL members in Czech society as indicated by our five sociodemographic variables reveals important results. The curvilinear disparity effects predicted by May [1973] on the basis of party position (member, sub-leader low, sub-leader high, and leader) are not observed for any of the policy scales. Kitschelt's [1989] predictions for curvilinear disparity among pragmatists and ideologues are only strongly evident in the case of attitudes toward abortion.

Using a theoretically informed case study of KDU-ČSL, this research has demonstrated that governing parties lose their representation function because those party members who are motivated more by representation than office become extinct. In the past, May [1973] and Kitschelt [1989] demonstrated the importance of 'radicals' in ensuring the balance between representation and responsibility. The disappearance of ideologues from mainstream parties of government is evident in the frequent failure by scholars to find curvilinear disparity patterns in contemporary political parties. Equally important is the fact that whatever differences of opinions exist in governing parties such as KDU-ČSL has little to do with party organisation. Our regression models demonstrate that sociodemographic factors, such as level of education, have much more powerful and consistent effects. This is a fascinating finding because it suggests that some form of sociological sorting process occurs in party recruitment and promotion. The failure to find strong evidence of May's law or Kitschelt revision of this law in party members' opinions and the absence of curvilinear disparities among party members reveal where within parties the representative role has failed. Governing parties without strongly opinionated sub-leaders or ideologues inevitably lose their representative function and hence their social anchoring in the electorate.

In this respect, the fate of KDU-ČSL is informative. The collapse of its vote in the 2010 general elections, and its replacement in parliament by two new (rather populist) parties demonstrates the likely fate of all governance oriented parties in the long-term. This same process of decline is also evident in the Czech Republic's two larger parties of government (ČSSD and ODS) who lost 1.4 million votes in the last election revealing the extent of public disenchantment with governing parties. The general lesson from the research presented in this study is that plans to redress the weakness of parties must start within parties and a reinvigoration of party membership. 
LUKÁš LINEK is a senior researcher in the Department of Political Sociology, Institute of Sociology, Academy of Sciences of the Czech Republic. His main research interests are voting behaviour, political parties, and mass political attitudes. He has recently published a book on the evolution of political attitudes in the Czech Republic over the last two decades (Zrazení snu? Struktura a dynamika postojů k politickému režimu a jeho institucí a jejich di̊sledky (Betrayal of the Dream? The Structure and Dynamics of Attitudes toward the Political Regime, and Its Institutions and Their Consequences), Prague 2010). He has published in Party Politics, Journal of Communist Studies and Transitional Politics, and the Journal of Legislative Studies.

PAT Lyons is a senior researcher in the Department of Political Sociology, Institute of Sociology, Academy of Sciences of the Czech Republic. His main areas of research are public opinion, political attitudes, electoral and legislative behaviour, and party politics. Recently he has completed a book length study of public and elite attitudes toward political reform during the Prague Spring era, which also compares Czech citizens' attitudes towards democracy in 1968 and 2008 (Mass and Elite Attitudes during the Prague Spring Era: Importance and Legacy, Prague 2009). He has published in Political Studies, Europe-Asia Studies, and Acta Politica.

\section{References}

Balík, Stanislav and Jiří Hanuš. 2007. Katolická církev v Československu 1945-1989. (The Catholic Church in Czechoslovakia 1945-1989) Brno: Centrum pro studium demokracie a kultury.

Butler, David A. 1960. 'The Paradox of Party Difference.' American Behavioral Scientist 4 (3): 3-5.

Costantini, Edmond. 1963. 'Intraparty Attitude Conflict: Democratic Party Leadership in California.' Western Political Quarterly 16 (4): 956-972.

Downs, Anthony. 1957. An Economic Theory of Democracy. New York: HarperCollins Publishers.

Duverger, Maurice. [1954] 1964. Political Parties: Their Organization and Activity in the Modern State. 3rd edition. London: Methuen.

Enyedi, Zsolt and Lukáš Linek. 2008. 'Searching for the Right Organization: Ideology and Party Structure in East-Central Europe.' Party Politics 14 (4): 455-477.

Epstein, Leon D. 1965. Political Parties in Western Democracies. New Brunswick, NJ: Transaction Books.

Fiala, Petr, Jiří Foral, Karel Konečný, Pavel Marek, Michal Pehr and Miloš Trapl. 2008. Český politický katolicismus 1848-2005. (Czech Political Catholicism 1848-2005) Brno: Centrum pro studium demokracie a kultury.

Fiala, Petr, Miroslav Mareš and Pavel Pšeja. 1999. ‘The Development of Political Parties and the Party System.' Pp. 273-294 in Ten Years of Rebuilding Capitalism: Czech Society after 1989, edited by J. Večerník and P. Matějů. Prague: Academia.

Grzymala-Busse, Anna. 2011. 'Why There Is (Almost) No Christian Democracy in Post-Communist Europe.' Party Politics. Retrieved 10 June 2011 (http://ppq.sagepub. com/content/early/2011/06/09/1354068811407596.full.pdf+html). 
Haute, van Emilie and R. Kenneth Carty. 2011. 'Ideological Misfits: A Distinctive Class of Party Member.' Party Politics. Retrieved 9 June 2011 ( http://ppq.sagepub.com/ content/early/2011/06/08/1354068810395058.full.pdf+html).

Herrera, Richard and Melanie K. Taylor. 1994. 'The Structure of Opinion in American Political Parties.' Political Studies 42 (4): 676-689.

Iversen, Torben. 1994. 'The Logics of Electoral Politics: Spatial, Directional, and Mobilization Effects.' Comparative Political Studies 27 (2): 155-189.

Jackson, John S., Barbara L. Brown and David Bositis. 1982. 'Herbert McClosky and friends revisited; 1980 Democratic and Republican Party Elites Compared to the Mass Publics.' American Politics Quarterly 10 (2): 158-180.

Kennedy, Fiachra, Pat Lyons and Peter Fitzgerald. 2006. 'Pragmatists, Ideologues and the General Law of Curvilinear Disparity: The Case of the Irish Labour Party.' Political Studies 54 (4): 786-805.

Key, Valdimer O. [1942] 1958. Politics, Parties, and Pressure Groups. 4th edition. New York: Crowell.

Kitschelt, Herbert. 1989. 'The Internal Politics of Parties: The Law of Curvilinear Disparity Revisited.' Political Studies 37 (3): 400-421.

Kostelecký, Tomáš. 2002. Political Parties after Communism: Developments in East-Central Europe. Washington, DC, and Baltimore, MD: Woodrow Wilson Centre/Johns Hopkins University Press.

Linek, Lukáš. 2011. 'The Czech Republic.' European Journal of Political Research 50 (7-8): 948-954.

Linek, Lukáš and Pat Lyons. 2008. 'Does Party Organization Still Matter in the Czech Republic? An Examination of the Czech Christian Democratic Party.' Transitions 48 (1): 103-131.

Linek, Lukáš and Štěpán Pecháček. 2006. 'Základní charakteristiky členské základny KDU-ČSL.' (The Basic Characteristics of the Membership Base of KDU-ČSL) Sociologické studie 6:06. Prague: Sociologický ústav AV ČR.

Lukeš, Bohumil. 2004. 'Československá strana lidová.' (Czechoslovak People’s Party) Pp. 1283-1306 in Politické strany II. 1938-2004, edited by J. Malíř and P. Marek. Brno: Doplněk.

Mair, Peter. 2005. 'Democracy Beyond Parties.' CSD Working Paper 05/06. Irvine, CA: Center for the Study of Democracy, University of California.

Mair, Peter. 2008. 'The Challenge to Party Government.' West European Politics 31 (1/2): 211-234.

Mair, Peter. 2009. 'Representative versus Responsible Government.' MPIfG Working Paper 09/8. Cologne: Max Planck Institute for the Study of Societies.

Mair, Peter. 2011. 'Smaghi vs the Parties: Representative Government and Institutional Constraints.' Paper presented at the conference on 'Democracy in Straightjackets: Politics in an Age of Permanent Austerity'. Munich, Germany, 23-26 March.

May, John D. 1973. 'Opinion Structure of Political Parties: The Special Law of Curvilinear Disparity.' Political Studies 21 (2): 135-151.

McCloskey, Herbert, Paul J. Hoffmann and Rosemary O'Hara. 1960. 'Issue Conflict and Consensus among Party Leaders and Followers.' American Political Science Review 54 (2): 406-427.

Michels, Robert. [1962] 2009. Political Parties: A Sociological Study of the Oligarchical Tendencies of Modern Democracy. 6th edition. New Brunswick, NJ: Transaction Publishers.

Narud, Hanne M. and Audun Skare. 1999. 'Are Party Activists the Party Extremists? The Structure of Opinion in Political Parties.' Scandinavian Political Studies 22 (1): 44-65. 
Norris, Pippa. 1995. 'May's Law of Curvilinear Disparity Revisited: Leaders, Officers, Members and Voters in British Political Parties.' Party Politics 1 (1): 29-47.

Ostrogorski, Moisei I. 1910. Democracy and the Party System in the United States: A Study in Extra-Constitutional Government. New York: The Macmillan Company.

Rapoport, Ronald B., Allan I. Abramowitz and John McGlennon (eds.). 1986. The Life of Parties: Activists in Presidential Politics. Lexington, KY: University of Kentucky Press.

Rose, Richard. 1974. Politics in England. 2nd edition. London: Faber.

Searing, Donald. D. 1986. 'A Theory of Political Socialization: Institutional Support and Deradicalization in Britain.' British Journal of Political Science 16 (3): 341-376.

Seyd, Patrick and Paul Whiteley. 1992. Labours Grass Roots: The Politics of Party Membership. Oxford: Oxford University Press.

Seyd, Patrick and Paul Whiteley. 2002. 'New Labour's Grassroots: The Transformation of the Labour Party Membership.' Basingstoke: Palgrave Macmillan.

Soule, John W. and James W. Clarke. 1971. 'Issue Conflict and Consensus: A Comparative Study of Democratic and Republican Delegates to the 1968 National Conventions.' Journal of Politics 33 (1): 72-91.

Trapl, Miloš. 2000. 'Katolické strany do roku 1938. ČSL v letech 1945-1948. Politické strany v exilu.' (Catholic Parties to 1938: Czechoslovak People's Party 1945-1948) Pp. 151-159, 305-308, 347-358 in Přehled politického stranictví na území českých zemí a Československa v letech 1861-1998, edited by P. Marek et al. Olomouc: Gloria.

Trapl, Miloš. 2004a. 'Československá strana lidová.' (Czechoslovak People's Party) Pp. 655-681 in Politické strany I. 1861-1938, edited by J. Malír and P. Marek. Brno: Doplněk.

Trapl, Miloš. 2004b. ‘Československá strana lidová.' (Czechoslovak People's Party) Pp. 1175-1187 in Politické strany II. 1938-2004, edited by J. Malíř and P. Marek. Brno: Doplněk.

Whiteley, Paul and Patrick Seyd. 2002. High-Intensity Participation: The Dynamics of Party Activism in Britain. Ann Arbor, MI: Michigan University Press.

Whiteley, Paul, Patrick Seyd and Jeremy Richardson. 1994. True Blues: The Politics of Conservative Party Membership. Oxford: Oxford University Press. 


\section{Appendix 1: Description of the surveys used}

\section{KDU-ČSL Party Membership Survey (May-August 2005)}

This postal survey of party members was undertaken between May and August 2005. This survey contains seventy-seven questions dealing with (1) joining the party, (2) contact with the local party organisation, (3) activity within the party, (4) political attitudes, (5) attitudes toward the party, (6) attitudes toward politicians and (7) political sympathies. For examining May's law there are ten issue scales in this survey that were replicated in the Czech National Election Study (2006). A total of 776 completed questionnaires were received. The response rate for this survey was $37 \%$. The resulting dataset is stratified into party members and higher party officials. Party members were selected using a stratified random sampling technique. Higher party officials were not randomly selected because of their relatively small number in the party organisation. All of them were included in the sample and many of these officials were interviewed. Consequently, this dataset has two weighting variables. The first one corrects for regional imbalances in members' response rate. Higher party officials have no regional affiliation and are thus given a zero weight. The second weighting variable reflects the hierarchical structure of the party. Here higher party officials although constituting $17 \%$ of the total dataset constitute less than one percent of the total party membership. In order, to calculate estimates of issue positions for the various party strata a third weight was constructed that weights party members for regional imbalances and gives higher party members a weight of one. By adopting this strategy it is possible to ensure that party members' estimates are not biased, e.g. region is associated with specific value orientations such social conservatism. Moreover, the numbers of cases for examining higher party officials' attitudes are of a reasonable size. This third weighting scheme is only used when each party strata is examined separately. All regression and principal component analyses use unweighted data as the central goal of these analyses is to determine the relationship between variables, rather than accurate parameter estimates. These research strategies are not ideal. However, use of the regional or hierarchical weighting variables effectively removes higher party members from consideration-a situation that would prohibit examining May's law.

\section{Questions from KDU-ČSL Party Membership Survey}

\section{(1) Questions used for party stratification}

Q22: Have you recently held any function within the party? (Yes/no)

Q22a: What function, and since when? (Three open-ended responses allowed)

Q23: Did you have any function in the party in the past? (Yes/no)

Q23a: If yes, what function? (Three open-ended responses allowed) 
Q24a: Are you currently a representative in the following bodies (1) Local Authority, (2) Regional Council, (3) Parliament, and (4) European Parliament?

Q24b: In the past, were you ever a representative in the following bodies (1) Local Authority, (2) Regional Council, (3) Parliament, and (4) European Parliament?

Q24c: Have you ever been a candidate in elections to the following bodies (1) Local Authority, (2) Regional Council, (3) Parliament and (4) European Parliament?

\section{(2) Question used for definition of pragmatists vs ideologues}

Q52: The following are selected statements about party politics. We would like to know if you agree or disagree. Please select one option from each line. Response options were: (1) Definitely agree, (2) Agree, (3) Disagree, and (4) Definitely disagree.

(g) Party leaders should listen more to party voters than to party members.

\section{(3) Policy issue scales}

Q37: In politics, people talk about left and right. On this scale where would you place yourself where ' 1 ' is most to the left and ' 10 ' is most to the right?

Q39: There are different opinions among the public on how many foreigners and immigrants our country can take. Some people think that we have already taken too many, while others say we can take much more. On the following scale ' 1 ' means that we should take much less and ' 10 ' means we can take much more than today. Where on this scale would you place your opinion?

Laws on migration and asylum should Laws on migration and asylum should be much more strict for foreigners (1)

be less strict for foreigners (10)

Q40: There exists a debate among parties about whether and to what extent the state should regulate the economy. On the following scale ' 1 ' means that the state has responsibility for the economic situation of the country and therefore has to intervene in the economy and ' 10 ' means that state interference in the economy should be minimal. Where on this scale would you place your opinion?

State should intervene in the economy

State interference in the economy should be minimal (10) 
Q41: Another political debate is whether the state should give priority to the development of the economy or protection of the economy. On the following scale ' 1 ' means that economic production should be increased and should be preferred to environmental issues and ' 10 ' means that environmental issues should be given priority over economic production. Where on this scale would you place your opinion?

Give priority to the economy (1)

Give priority to the environment (10)

Q42: Some people say that European integration should be deepened; others say that integration has gone too far. On the following scale ' 1 ' means integration has gone too far and ' 10 ' means accession should be deepened. Where on this scale would you place your opinion?

Integration should be deepened (1)

Integration has gone too far (10)

Q43: There exists different opinions among the public and political parties on aspects of human life and with it laws on abortion. On the following scale ' 1 ' means that abortion should be made illegal and ' 10 ' means that a woman has the right to decide on her pregnancy and its termination. Where on this scale would you place your opinion?

State should abolish abortion (1)

A woman has the right to decide (10)

Q44: There exists a dispute among people about the size of the public sector. On the following scale ' 1 ' means that state redistribution should be lower while ' 10 ' means that redistribution and spending should be higher in the future. Where on this scale would you place your opinion?

Less state redistribution (1)

More state redistribution (10)

Q45: Some parties have different opinions on how to fight crime. On the following scale ' 1 ' means that we need to actively fight crime even though this involves limiting civil liberties, while ' 10 ' means that crime needs to be tackled but not at the expense of civil liberties. Where on this scale would you place your opinion? Ensure security (1)

Ensure civil liberties (10) 
Q46: People have difference incomes and thus taxes. On the following scale ' 1 ' means people with high incomes should pay higher taxes than those with lower incomes, while ' 10 ' means everyone should pay the same tax. Where on this scale would you place your opinion?

Progressive taxation (1)

Flat tax rate (10)

Q47: Politicians discuss the rationality of state help to agriculture. On the following scale ' 1 ' means that farmers should get no subventions and ' 10 ' means that farmers should get subventions from the state. Where on this scale would you place your opinion?

No state aid for farmers (1)

State aid for farmers (10)

Q49: Politicians are in disagreement about the provision of public services to citizens. On the following scale ' 1 ' means citizens alone should bear a significant part of the costs for education, health, pensions, etc., while ' 10 ' means that the state should pay a significant portion of these expenses. Where on this scale would you place your opinion?

Citizens should pay most of the costs

for health, education, etc. (1)
The state should pay most of the costs for health, education, etc. (10)

\section{Czech National Election Study (June 2006)}

The Czech National Election Survey was undertaken between 9 and 21 June, within one week of the Chamber elections. The survey was administered by the Public Opinion Research Centre (CVVM), a specialised section within the Institute of Sociology of the Academy of Sciences of the Czech Republic. This face-to-face national survey was conducted among 2002 adults aged eighteen years and older using quota sampling stratified using probability proportional to weight on the basis of region, size of community, sex, age, and education. The sample is representative of the entire territory of the Czech Republic. For comparison between the 10-point party membership issue scales and the 11-point CNES ones the latter were re-scaled to 10-point scales.

\section{Questions from the Czech National Election Study}

Q21/22: In politics, people often talk about the left and the right. Using the 0-10 scale, 0 meaning left and 10 meaning right, where would you place yourself on this scale? 
Q29: We would like to know your opinion on particular issues, now. Where would you place your opinion on the following scale? (0-10 point scale)

Definitely agree with the first opinion Definitely agree with the second opin(0) ion (10)

People themselves should be responsi- The state is responsible for the signifible for most of the costs of healthcare, cant part of those costs (10) education, etc. (0)

All state-owned enterprises should be A significant part of companies and privatised (0) enterprises should be state-owned (10)

People with higher income should pay Everybody should pay the same tax rate a higher tax rate $(0)$

Immigration laws should be more strict Immigration laws should be less strict (0)

The state should outlaw abortion (0) It's up to a woman to decide about abortion (10)

European integration should be deep- European integration has gone too far ened (0)

Farmers shouldn't get subventions (0) Farmers should get subventions (10)

Economy growth should get priority over protecting the environment (0)

Protecting the environment should get

The fight against crime is necessary

even if it could limit citizen rights and liberties (0) priority over economic growth (10)

Fighting against crime is necessary, but citizen rights and liberties must not be limited (10)

The state should not intervene in the economy (0)

The state should intervene in the economy to ensure that it performs well (10) 


\section{Appendix 2: Regression tables}

Table A1. Model of self-placement on various issue scales by position within KDU-ČSL and selected background variables

\begin{tabular}{|c|c|c|c|c|c|c|c|c|}
\hline \multirow[t]{2}{*}{ Variables } & \multicolumn{2}{|c|}{ Left-right } & \multicolumn{2}{|c|}{$\begin{array}{l}\text { Migration } \\
\text { \& asylum }\end{array}$} & \multicolumn{2}{|c|}{$\begin{array}{l}\text { State } \\
\text { regulation }\end{array}$} & \multicolumn{2}{|c|}{$\begin{array}{c}\text { Econ. vs } \\
\text { environment }\end{array}$} \\
\hline & B & SE & B & SE & B & SE & B & SE \\
\hline Party member & -.02 & .24 & -.31 & .29 & -.47 & .31 & .40 & .29 \\
\hline Sub-leader low & -.43 & .23 & -.44 & .28 & -.24 & .30 & .20 & .28 \\
\hline Leader & -.20 & .29 & .41 & .36 & .80 & .38 & -.25 & .36 \\
\hline Age (x 10 years) & .04 & .06 & -.02 & .07 & -.09 & .08 & .03 & .07 \\
\hline Education & -.19 & .09 & .39 & .10 & .43 & .11 & .08 & .10 \\
\hline $\begin{array}{l}\text { Bohemia } \\
\text { vs Moravia }\end{array}$ & .42 & .15 & -.37 & .19 & -.41 & .20 & .09 & .19 \\
\hline Old/new member & -.17 & .17 & -.27 & .20 & -.41 & .22 & -.21 & .20 \\
\hline Family member & -.06 & .16 & -.23 & .19 & -.29 & .21 & -.35 & .19 \\
\hline Intercept & 7.35 & .59 & 4.72 & .72 & 6.29 & .77 & 6.62 & .72 \\
\hline $\mathrm{R}$ & .22 & & .28 & & .33 & & .12 & \\
\hline R Square & .05 & & .08 & & .11 & & .01 & \\
\hline Adj. R square & .03 & & .07 & & .10 & & $<.01$ & \\
\hline SE of Est. & 1.78 & & 2.24 & & 2.38 & & 2.23 & \\
\hline $\mathrm{N}$ & 561 & & 595 & & 587 & & 600 & \\
\hline
\end{tabular}


Table A1. Model of self-placement on various issue scales by position within KDU-ČSL and selected background variables-continued

\begin{tabular}{|c|c|c|c|c|c|c|c|c|}
\hline \multirow[t]{2}{*}{ Variables } & \multicolumn{2}{|c|}{$\begin{array}{l}\text { European } \\
\text { integration }\end{array}$} & \multicolumn{2}{|c|}{ Abortion } & \multicolumn{2}{|c|}{$\begin{array}{l}\text { Size of public } \\
\text { sector }\end{array}$} & \multicolumn{2}{|c|}{$\begin{array}{l}\text { Security vs } \\
\text { civil liberties }\end{array}$} \\
\hline & B & SE & B & SE & B & SE & B & SE \\
\hline Party member & -.43 & .30 & .16 & .41 & .23 & .31 & .56 & .41 \\
\hline Sub-leader low & -.18 & .29 & .26 & .40 & .17 & .30 & .38 & .39 \\
\hline Leader & .04 & .37 & .05 & .50 & -.72 & .38 & -.37 & .50 \\
\hline Age (x 10 years) & .07 & .07 & -.15 & .10 & .23 & .08 & -.22 & .10 \\
\hline Education & .26 & .11 & -.19 & .15 & -.17 & .11 & -.34 & .14 \\
\hline $\begin{array}{l}\text { Bohemia } \\
\text { vs Moravia }\end{array}$ & -.21 & .19 & -.80 & .27 & -.13 & .20 & .13 & .26 \\
\hline Old/new member & -.37 & .21 & .13 & .29 & -.30 & .22 & -.28 & .28 \\
\hline Family member & -.04 & .20 & -.25 & .27 & .15 & .20 & .11 & .27 \\
\hline Intercept & 6.68 & .75 & 6.31 & 1.02 & 4.61 & .77 & 7.40 & 1.00 \\
\hline $\mathrm{R}$ & .18 & & .15 & & .28 & & .18 & \\
\hline R Square & .03 & & .02 & & .08 & & .03 & \\
\hline Adj. R square & .02 & & .01 & & .07 & & .02 & \\
\hline SE of Est. & 2.28 & & 3.15 & & 2.32 & & 3.11 & \\
\hline $\mathrm{N}$ & 579 & & 594 & & 564 & & 599 & \\
\hline
\end{tabular}


Table A1. Model of self-placement on various issue scales by position within KDU-ČSL and selected background variables-continued

\begin{tabular}{|c|c|c|c|c|c|c|}
\hline \multirow[t]{2}{*}{ Variables } & \multicolumn{2}{|c|}{$\begin{array}{c}\text { Tax: progres- } \\
\text { sive vs } \\
\text { flat rate }\end{array}$} & \multicolumn{2}{|c|}{$\begin{array}{l}\text { State aid } \\
\text { to farmers }\end{array}$} & \multicolumn{2}{|c|}{$\begin{array}{l}\text { Provision } \\
\text { of public } \\
\text { services }\end{array}$} \\
\hline & B & SE & B & SE & B & SE \\
\hline Party member & -.25 & .33 & .34 & .28 & .34 & .28 \\
\hline Sub-leader low & -.32 & .31 & .39 & .27 & .24 & .27 \\
\hline Leader & .26 & .40 & -.19 & .34 & -1.06 & .34 \\
\hline Age (x 10 years) & -.20 & .08 & .04 & .07 & .14 & .07 \\
\hline Education & .35 & .12 & -.25 & .10 & -.37 & .10 \\
\hline $\begin{array}{l}\text { Bohemia } \\
\text { vs Moravia }\end{array}$ & -.43 & .21 & .54 & .18 & .19 & .18 \\
\hline Old/new member & -.38 & .23 & -.29 & .19 & -.15 & .19 \\
\hline Family member & -.09 & .21 & .01 & .18 & -.14 & .18 \\
\hline Intercept & 4.97 & .80 & 7.61 & .69 & 7.59 & .69 \\
\hline $\mathrm{R}$ & .27 & & .26 & & .36 & \\
\hline R Square & .07 & & .07 & & .13 & \\
\hline Adj. R square & .06 & & .06 & & .12 & \\
\hline SE of Est. & 2.50 & & 2.15 & & 2.15 & \\
\hline $\mathrm{N}$ & 601 & & 610 & & 604 & \\
\hline
\end{tabular}

Source: KDU-ČSL Membership Survey 2005.

Note: Coefficients in bold are significant $(\mathrm{p} \leq .05)$. OLS regression analyses based on unweighted data. 
Table A2. Model of self-placement on various issue scales by ideologue/pragmatist orientation and selected background variables

\begin{tabular}{|c|c|c|c|c|c|c|c|c|}
\hline \multirow[t]{2}{*}{ Variables } & \multicolumn{2}{|c|}{ Left-right } & \multicolumn{2}{|c|}{$\begin{array}{l}\text { Migration \& } \\
\text { asylum }\end{array}$} & \multicolumn{2}{|c|}{$\begin{array}{l}\text { State regula- } \\
\text { tion }\end{array}$} & \multicolumn{2}{|c|}{$\begin{array}{l}\text { Econ. vs envi- } \\
\text { ronment }\end{array}$} \\
\hline & B & SE & B & SE & B & SE & B & SE \\
\hline Strong pragmatist & -.17 & .22 & -.27 & .27 & -.61 & .29 & -.41 & .27 \\
\hline Mild ideologue & -.09 & .17 & .17 & .21 & -.02 & .23 & -.09 & .21 \\
\hline Strong ideologue & .36 & .40 & -.18 & .48 & -.02 & .52 & -.37 & .48 \\
\hline Age (x 10 years) & .03 & .06 & -.03 & .07 & -.12 & .08 & .04 & .07 \\
\hline Education & -.20 & .08 & .47 & .10 & .56 & .10 & -.01 & .09 \\
\hline $\begin{array}{l}\text { Bohemia vs } \\
\text { Moravia }\end{array}$ & .39 & .16 & -.41 & .19 & -.44 & .20 & .09 & .19 \\
\hline $\begin{array}{l}\text { Old/new } \\
\text { member }\end{array}$ & -.18 & .17 & -.30 & .20 & -.46 & .22 & -.17 & .20 \\
\hline Family member & -.05 & .16 & -.21 & .19 & -.26 & .21 & -.35 & .19 \\
\hline Intercept & 7.33 & .58 & 4.46 & .71 & 6.14 & .76 & 7.01 & .70 \\
\hline $\mathrm{R}$ & .20 & & .27 & & .32 & & .11 & \\
\hline R Square & .04 & & .07 & & .10 & & .01 & \\
\hline Adj. R square & .03 & & .06 & & .09 & & $<.01$ & \\
\hline SE of Est. & 1.79 & & 2.25 & & 2.39 & & 2.23 & \\
\hline $\mathrm{N}$ & 561 & & 595 & & 587 & & 600 & \\
\hline
\end{tabular}


Table A2. Model of self-placement on various issue scales by ideologue/pragmatist orientation and selected background variables-continued

\begin{tabular}{|c|c|c|c|c|c|c|c|c|}
\hline \multirow[t]{2}{*}{ Variables } & \multicolumn{2}{|c|}{$\begin{array}{l}\text { European } \\
\text { integration }\end{array}$} & \multicolumn{2}{|c|}{ Abortion } & \multicolumn{2}{|c|}{$\begin{array}{l}\text { Size of public } \\
\text { sector }\end{array}$} & \multicolumn{2}{|c|}{$\begin{array}{l}\text { Security vs } \\
\text { civil liberties }\end{array}$} \\
\hline & B & SE & B & SE & B & SE & B & SE \\
\hline Strong pragmatist & -.16 & .28 & 1.27 & .37 & .37 & .29 & .04 & .38 \\
\hline Mild ideologue & .01 & .22 & -1.35 & .28 & -.16 & .22 & -.12 & .29 \\
\hline Strong ideologue & -.20 & .50 & -1.44 & .65 & -.35 & .51 & .58 & .67 \\
\hline Age (x 10 years) & .06 & .07 & -.16 & .10 & .25 & .08 & -.21 & .10 \\
\hline Education & .33 & .10 & -.06 & .13 & -.25 & .10 & -.46 & .13 \\
\hline $\begin{array}{l}\text { Bohemia vs } \\
\text { Moravia }\end{array}$ & -.22 & .19 & -.75 & .25 & -.10 & .20 & .15 & .26 \\
\hline $\begin{array}{l}\text { Old/new } \\
\text { member }\end{array}$ & -.41 & .21 & .17 & .27 & -.27 & .22 & -.22 & .28 \\
\hline Family member & -.04 & .20 & -.22 & .26 & .13 & .21 & .11 & .27 \\
\hline Intercept & 6.47 & .73 & 6.34 & .95 & 4.72 & .75 & 7.83 & .98 \\
\hline $\mathrm{R}$ & .17 & & .32 & & .27 & & .17 & \\
\hline R Square & .03 & & .10 & & .07 & & .03 & \\
\hline Adj. R square & .02 & & .09 & & .06 & & .01 & \\
\hline SE of Est. & 2.28 & & 3.01 & & 2.33 & & 3.12 & \\
\hline $\mathrm{N}$ & 579 & & 594 & & 564 & & 599 & \\
\hline
\end{tabular}


Table A2. Model of self-placement on various issue scales by ideologue/pragmatist orientation and selected background variables-continued

\begin{tabular}{|c|c|c|c|c|c|c|}
\hline \multirow[t]{2}{*}{ Variables } & \multicolumn{2}{|c|}{$\begin{array}{l}\text { Tax: progres- } \\
\text { sive vs } \\
\text { flat rate }\end{array}$} & \multicolumn{2}{|c|}{$\begin{array}{l}\text { State aid } \\
\text { to farmers }\end{array}$} & \multicolumn{2}{|c|}{$\begin{array}{l}\text { Provision } \\
\text { of public } \\
\text { services }\end{array}$} \\
\hline & B & SE & B & SE & B & SE \\
\hline Strong pragmatist & -.05 & .30 & -.05 & .26 & .67 & .26 \\
\hline Mild ideologue & -.03 & .23 & -.04 & .20 & -.20 & .20 \\
\hline Strong ideologue & -.04 & .53 & .07 & .46 & .52 & .46 \\
\hline Age (x 10 years) & -.21 & .08 & .05 & .07 & .15 & .07 \\
\hline Education & .42 & .11 & -.32 & .09 & -.49 & .09 \\
\hline $\begin{array}{l}\text { Bohemia vs } \\
\text { Moravia }\end{array}$ & -.45 & .21 & .57 & .18 & .24 & .18 \\
\hline Old/new member & -.41 & .22 & -.26 & .19 & -.12 & .19 \\
\hline Family member & -.07 & .21 & .00 & .18 & -.17 & .18 \\
\hline Intercept & 4.77 & .79 & 7.91 & .67 & 7.74 & .68 \\
\hline $\mathrm{R}$ & .26 & & .25 & & .35 & \\
\hline R Square & .07 & & .06 & & .12 & \\
\hline Adj. R square & .06 & & .05 & & .11 & \\
\hline SE of Est. & 2.50 & & 2.15 & & 2.16 & \\
\hline $\mathrm{N}$ & 601 & & 610 & & 604 & \\
\hline
\end{tabular}

Source: KDU-ČSL Membership Survey 2005.

Note: Coefficients in bold are significant $(\mathrm{p} \leq .05)$. OLS regression analyses based on unweighted data. 